This item was submitted to Loughborough's Research Repository by the author.

Items in Figshare are protected by copyright, with all rights reserved, unless otherwise indicated.

\title{
Urban ponds as an aquatic biodiversity resource in modified landscapes
}

PLEASE CITE THE PUBLISHED VERSION

http://dx.doi.org/10.1111/gcb.13401

PUBLISHER

(c) Wiley

VERSION

AM (Accepted Manuscript)

PUBLISHER STATEMENT

This work is made available according to the conditions of the Creative Commons Attribution-NonCommercialNoDerivatives 4.0 International (CC BY-NC-ND 4.0) licence. Full details of this licence are available at: https://creativecommons.org/licenses/by-nc-nd/4.0/

\section{LICENCE}

CC BY-NC-ND 4.0

\section{REPOSITORY RECORD}

Hill, Matthew J., Jeremy Biggs, lan Thornhill, Robert A. Briers, David G. Gledhill, James C. White, Paul Wood, and Christopher Hassall. 2016. "Urban Ponds as an Aquatic Biodiversity Resource in Modified Landscapes". Loughborough University. https://hdl.handle.net/2134/22276. 
2 Running head: Macroinvertebrate biodiversity in urban aquatic ecosystems

3 Type of paper: Primary Research Article

4 Hill, M. J. ${ }^{1}$, Biggs, J. ${ }^{2}$, Thornhill, I. ${ }^{3}$, Briers, R. A. ${ }^{4}$, Gledhill, D. H. ${ }^{5}$, White, J. C. ${ }^{6}$, Wood. P. J. ${ }^{6}$

5 and Hassall, C. ${ }^{7}$

$6 \quad{ }^{1}$ Institute of Science and the Environment, University of Worcester, Worcester,

$7 \quad$ Worcestershire, WR2 6AJ, UK

$8 \quad{ }^{2}$ Freshwater Habitats Trust, Bury Knowle House, Headington, Oxford, OX3 9HY

$9 \quad{ }^{3}$ University of Birmingham, Edgbaston, Birmingham, B15 2TT, UK

$10{ }^{4}$ School of Life, Sport and Social Sciences, Edinburgh Napier University, Edinburgh, UK

$11{ }^{5}$ Ecosystems \& Environment Research Centre, School of Environment and Life Sciences,

12 Peel Building, University of Salford, Salford, Greater Manchester M5 4WT, UK

$13{ }^{6}$ Centre for Hydrological and Ecosystem Science, Department of Geography, Loughborough

14 University, Loughborough, Leicestershire, LE11 3TU, UK

$15 \quad{ }^{7}$ School of Biology, University of Leeds, Woodhouse Lane, Leeds, LS2 9JT, UK

\section{Author for correspondence}

17 Christopher Hassall

18 School of Biology

19 University of Leeds

20 Woodhouse Lane

21 Leeds

22 LS2 9JT, UK

23 Tel: $0044(0) 1133435578$

24 Email: c.hassall@leeds.ac.uk 
25 Keywords: urban, city, ecology, freshwater, aquatic, biodiversity, biotic homogenisation, 26 conservation, invertebrate. 


\section{Abstract}

28 Urbanization is a global process contributing to the loss and fragmentation of natural habitats.

29 Many studies have focused on the biological response of terrestrial taxa and habitats to

30 urbanization. However, little is known regarding the consequences of urbanization on freshwater

31 habitats, especially small lentic systems. In this study we examined aquatic macroinvertebrate

32 diversity (family and species level) and variation in community composition between 240 urban

33 and 782 non-urban ponds distributed across the UK. Contrary to predictions, urban ponds

34 supported similar numbers of invertebrate species and families compared to non-urban ponds.

35 Similar gamma diversity was found between the two groups at both family and species

36 taxonomic levels. The biological communities of urban ponds were markedly different to those

37 of non-urban ponds and the variability in urban pond community composition was greater than

38 that in non-urban ponds, contrary to previous work showing homogenisation of communities in

39 urban areas. Positive spatial autocorrelation was recorded for urban and non-urban ponds at 0-50

$40 \mathrm{~km}$ (distance between pond study sites) and negative spatial autocorrelation was observed at 100-

$41150 \mathrm{~km}$, and was stronger in urban ponds in both cases. Ponds do not follow the same ecological

42 patterns as terrestrial and lotic habitats (reduced taxonomic richness) in urban environments; in

43 contrast they support high taxonomic richness and contribute significantly to regional faunal

44 diversity. Individual cities are complex structural mosaics which evolve over long periods of

45 time and are managed in diverse ways, promoting the development of a wide-range of

46 environmental conditions and habitat niches in urban ponds which can promote greater

47 heterogeneity between pond communities at larger scales. Ponds provide an opportunity for

48 managers and environmental regulators to conserve and enhance freshwater biodiversity in 
49 urbanized landscapes whilst also facilitating key ecosystem services including storm water 50 storage and water treatment. 
52 Land use change has been predicted to be the greatest driver of biodiversity change in the $21^{\text {st }}$

53 century (Sala et al., 2000). The conversion of natural landscapes to urban areas represents a

54 common land use transition, and is a significant process contributing to the loss of freshwater

55 habitats and the degradation of those that remain, placing considerable pressure on native flora

56 and fauna (McKinney, 2002). The fragmentation of natural habitats and development of uniform

57 landscapes in urban areas has been demonstrated to cause the biotic homogenization of flora and

58 fauna through the decline and exclusion of native species by land use modification (and

59 associated anthropogenic pressures) and the establishment and spread of non-native invasive

60 species through habitat disturbance and human introductions (McKinney, 2006; Grimm et al.,

61 2008; Shochat et al., 2010). Previous research has demonstrated that high levels of urbanization

62 reduce macroinvertebrate and macrophyte species richness (e.g. in urban streams, Roy et al.,

63 2003; Walsh et al., 2005) to the point where urban environments are viewed as 'ecological

64 deserts'; although at moderate levels of urbanization greater diversity has been recorded for plant

65 communities (McKinney et al., 2008). In recent decades, significant improvements to the

66 physical, chemical and ecological quality of urban freshwater ecosystems have been made in

67 economically developed nations reflecting the decline in industrial developments, improved

68 waste water treatment, and more effective environmental legislation (e.g., The Water Framework

69 Directive in Europe; EC, 2000 and The Water Act 2007 in Australia; Commonwealth of

70 Australia, 2007). Although there have been significant improvements to the quality of many

71 urban aquatic habitats, the number of water bodies in urban areas has declined over the past

72 century (Wood et al., 2003; Vaughan \& Ormerod, 2012; Thornhill, 2013). Commercial and

73 residential developments are expanding in urban areas to keep pace with population growth (66\% 
74 of global urban population are predicted to live in urban areas by 2050; United Nations, 2014) at

75 the expense of urban green spaces (Dallimer et al., 2011). Such losses of green/blue space are

76 likely to place significant pressure on remaining urban freshwaters to support native flora and

77 fauna and may lead to substantial shifts in the diversity and composition of species in urban areas

78 (Fitzhugh \& Richter, 2004; McKinney, 2006).

80 Ponds are ubiquitous habitat features in both urban and non-urban landscapes. In non-urban

81 landscapes ponds have been demonstrated to support greater regional diversity of flora and fauna

82 compared to rivers and lakes (Davies et al., 2008). This biodiversity value may result from

83 spatial and temporal diversity in pond environmental variables (Hassall et al., 2011; Hassall et

84 al., 2012), which create a highly heterogeneous "pondscape" of habitats that provide a diverse

85 array of ecological niches. Ponds have been acknowledged as providing important network

86 connectivity across landscapes, acting as "stepping stones" that facilitate dispersal (Pereira et al.,

87 2011). Within urban areas, ponds provide a diverse array of habitats and occur in a wide range of

88 forms including garden ponds (Hill \& Wood, 2014), sustainable urban drainage systems (SUDS;

89 Briers, 2014; Hassall \& Anderson, 2015), industrial, ornamental and park ponds (Gledhill et al.,

90 2008; Hill et al., 2015), recreation and angling ponds (Wood et al., 2001), and nature reserve

91 ponds (Hassall, 2014) which typically display heterogeneous physicochemical conditions (Hill et

92 al., 2015). Urban ponds are almost always of anthropogenic origin and often demonstrate

93 different environmental characteristics to non-urban (semi-natural/agricultural) ponds; urban

94 ponds commonly have concrete margins, a synthetic base, reduced vegetation cover, lower

95 connectivity to other waterbodies, and are subject to run off from residential and industrial

96 developments which can greatly increase the concentration of contaminants (Hassall, 2014). 
97 While the definition of a "pond" versus a "lake" is still very much debated, a general rule is that 98 ponds are standing water bodies $<2$ ha in size. Urban waterbodies are frequently much smaller

99 (closer to $1-5 \mathrm{~m}^{2}$ for garden ponds) but show a large variation in size ( $>10$ ha for park lakes). For 100 a discussion of the definitions of ponds and lakes, we refer the reader elsewhere (Hassall, 2014; 101 Appendix 1 in Biggs et al., 2005). Despite the considerable anthropogenic pressures on urban 102 ponds, recent studies have demonstrated that ponds located within an urban matrix can provide 103 important habitats for a wide range of taxa including macroinvertebrates (Hassall, 2014;

104 Goertzen \& Suhling, 2015; Hill et al., 2015) and amphibians (Hamer et al., 2012). In addition, 105 many support comparable diversity to surrounding non-urban ponds (Hassall \& Anderson, 2015) 106 and also provide a wide range of ecosystems services in urban areas to offset the negative 107 impacts of urbanization (Hassall, 2014). However, these patterns are inconsistent, and other 108 studies have reported a lower diversity of macroinvertebrate and floral taxa in urban ponds 109 reflecting the greater isolation of pond habitats (Hitchings \& Beebee, 1997) and management 110 practices designed for purposes other than biodiversity (e.g., emergent vegetation removal, 111 Noble \& Hassall, 2014).

113 While there has been increasing research interest in the biodiversity and ecosystem services of 114 urban ponds across Europe (Hassall, 2014; Jeanmougin et al., 2014; Goertzen \& Suhling, 2015), 115 the question remains as to whether urban ponds can provide similar levels of biodiversity to that 116 recorded in ponds in the wider landscape. Few studies have compared urban pond faunal 117 communities with non-urban pond communities (see Hassall \& Anderson, 2015) and no known 118 studies have examined urban pond macroinvertebrate diversity at a national scale. Furthermore, 119 there are a series of ecological patterns within cities (e.g., reduced taxonomic diversity, biotic 
120 homogenization, increase in non-native and invasive taxa) that have been described in terrestrial

121 systems (particularly birds, butterflies, and plants: McKinney, 2008) but these have not been

122 tested in aquatic ecosystems. This study provides a comparative analysis of environmental

123 characteristics and macroinvertebrate communities contained within $>1000$ UK ponds, including

124 ponds located in a number of cities and towns across the UK and non-urban ponds that cover a

125 wide range of non-urban habitats including; nature reserves, agricultural land (pasture and crop),

126 meadows, woodland and other wetlands. We test the following hypotheses (i) urban ponds

127 support lower macroinvertebrate richness and diversity (family and species level) than non-urban

128 ponds, as would be predicted from the greater anthropogenic stressors in urban areas; (ii) urban

129 macroinvertebrate communities would be more homogeneous than non-urban communities at a

130 family and species scale, due to the greater similarity of urban habitats as has been reported for

131 terrestrial taxa; and (iii) urban pond communities demonstrate stronger spatial structuring at

132 smaller scales than non-urban communities, through reduced connectivity, dispersal and gene

133 flow.

135 Materials and Methods

136 Data Management

137 The UK covers a total area of $242,495 \mathrm{~km}^{2}$ and has a population of approximately 64.6 million

138 inhabitants. Over $6.8 \%$ of the UK land mass is classified as urban and approximately $80 \%$ of the

139 population resides in urban areas (defined as areas $>20$ ha containing $>20,000$ people, UKNEA,

140 2011). Aquatic macroinvertebrate community data from 230 urban and 607 non-urban ponds and

141 environmental data from 240 urban ponds and 782 non-urban ponds in the UK were collated 
142 from 12 previous studies (Table 1). The spatial distribution of the studied urban and non-urban 143 ponds is displayed in Figure 1. 
145 Data collection methodologies employed by the majority of contributing studies (Table 1)

146 broadly followed the standardized guidelines of the National Pond Survey (Biggs et al., 1998)

147 including a 3 minute sweep sample divided between the mesohabitats present (Studies 1, 2, 3, 4,

$1485,6,9,10,11$ and 12; Table 1). The other studies also sampled for aquatic macroinvertebrate

149 taxa in all available mesohabitats, but sampling was undertaken until no new species were

150 recorded (studies 7 and 8). The majority of studies were sampled across two or three seasons

151 (studies 1, 3, 4, 6, 7, 10 and 11; Table 1) although five studies were only sampled during the

152 summer months (studies 2, 5, 8, 9 and 12; Table 1). Environmental data recorded from pond sites

153 varied between studies, but always included a common core of variables that were used in the

154 comparative analysis: pond area, $\mathrm{pH}$, percentage coverage of emergent macrophytes, percentage

155 pond shading, and altitude. Ponds were categorized as urban or non-urban based on whether they

156 were located within developed land use areas (DLUAs) - a landscape designation used by the

157 UK-based Ordnance Survey to delineate urban and non-urban sites. We provide a comparison

158 between our binary categorisation and two other measures of 'urbanness' (proportion of urban

159 land use in a $1 \mathrm{~km}$ buffer, and distance from urban land use areas) in the Supplementary

160 Information (Part 1). We acknowledge that the definition of an urban pond is complex. Indeed, a

161 previous attempt to define a typology of urban ponds concluded that these sites comprise a

162 diverse array of different habitat types (Hassall, 2014). However, the intention with this study is

163 to evaluate the aquatic biodiversity in urban areas, and to establish whether those urban sites are

164 deserving of protection, value, and enhancement. Hence, rather than attempting to define the

165 precise characteristics of an "urban pond", we are focusing on the much more tractable issue of

166 "ponds in urban areas". Similarly, the definition of a "non-urban pond" for our purposes simply 
167 includes ponds outside of urban areas. Our non-urban pond dataset is concentrated in agricultural 168 landscapes which in the UK are typically characterised by low tree cover and low surrounding 169 botanical diversity, along with high inputs of nutrients and agricultural effluents. These ponds 170 are likely to be subject to "benign neglect" (i.e. limited management) but this will vary across the 171 ponds in the study. Urban ponds in this study encompass a broad spectrum of urban areas, from 172 their location in densely populated cities (e.g., Birmingham: population $>1$ million) to smaller 173 towns (e.g., Loughborough: estimated population of 60000). The urban ponds chosen for 174 investigation included ponds in domestic gardens, industrial ponds (old mill ponds), ornamental 175 ponds located in urban parks and drainage ponds (e.g., sustainable urban drainage systems / 176 stormwater retention ponds; see Hassall, 2014). The issue of the representative nature of UK 177 cities compared to cities elsewhere (in Europe or the wider world) is less clear for ponds, since 178 there has been limited study of these habitats using standardised methods (see Hassall, 2014, for 179 a discussion and a range of biodiversity studies). It is likely that the range of urbanised areas 180 incorporated in our study covers the range of different urban landscapes that are found in 181 European cities, from millennia-old cities with an evolving land use pattern (e.g. London), to 182 centuries-old industrial towns (e.g. Leeds, Manchester), to $20^{\text {th }}$ century towns which have been 183 designed and built de novo (e.g. Milton Keynes).

185 The faunal dataset was converted into a presence-absence matrix to ensure data provided by the 18612 constituent studies were comparable and that any sampling bias was reduced. Abundance data 187 may yield additional insights into variation in biomass and evenness among ponds, and we might 188 expect greater biomass and evenness in non-urban sites where stressors are reduced and nutrient supply is greater. However, our primary goal within the present study is to investigate variation 
190 in taxonomic richness across the pond types. Two key methodological differences exist in the 12

191 studies. First, although most of the corresponding studies identified the majority of

192 macroinvertebrate taxa to species level, each study also identified selected taxa (e.g., Diptera,

193 Oligochaeta, Copepoda and Ostracoda) at higher taxonomic levels (Table 1). The influence of a

194 higher taxonomic resolution of identification for aquatic macroinvertebrates has been examined,

195 primarily within lotic habitats (Monk et al., 2012; Heino, 2014). However, identification of

196 macroinvertebrate taxa at family level has been shown to be appropriate to examine alpha, beta

197 and gamma diversity in lentic systems (Le Viol et al., 2009; Mueller et al., 2013; Hassall \&

198 Anderson, 2015; Vilmi et al., 2016) and is the resolution used by a range of environmental

199 monitoring indices (e.g., biological monitoring working party [BMWP] and predictive system for

200 multimetrics [PSYM] scores; Environment Agency \& Pond Conservation Trust, 2002) and

201 legislation (e.g., The Water Framework Directive; EC, 2000) across Europe. However, to assess

202 the sensitivity of results to taxonomic resolution we performed all analyses at two taxonomic

203 levels: first, to incorporate as many sites as possible and to ensure faunal data was comparable

204 across all studies, aquatic macroinvertebrate data were reclassified to family level and analysis

205 was undertaken at this higher taxonomic resolution. Second, statistical analysis was also

206 undertaken on a subset of urban (207 ponds) and non-urban ponds (578 ponds) where species

207 level data was available.

209 The second methodological variation was in the amount of sampling effort applied to the sites:

210 sampling effort was limited to 3 minutes in 10 of the studies (following standard UK sampling

211 protocols) but two studies used exhaustive sampling until no more species were found. A

212 preliminary analysis showed that, in fact, the sites sampled for 3 minutes found more taxa 
213 (average of $14.7 \pm 0.4$ SE families, $n=392$ sites; average of $30.0 \pm 0.9$ species, $n=340$ ) than sites

214 sampled exhaustively (average of $13.6 \pm 0.3$ SE families, $n=518$ sites; average of $26.8 \pm 0.6$

215 species, $\mathrm{n}=518$ ). However, this lower number of species in exhaustive samples is likely to result

216 from those sites occurring in the north of England where the regional species pool may be

217 smaller. As a result, we find no evidence of bias between the exhaustive and time-limited

218 samples. Finally, to provide the strongest possible test of the biodiversity value of urban ponds,

219 urban pond communities (at a family and species level) were compared to a subset of the non-

220 urban ponds with degraded sites excluded (leaving $n=571$ non-urban ponds with family level

221 data and 542 with species level data).

Statistical Analysis

224 Differences in environmental characteristics (pond area, percentage coverage of emergent

225 macrophytes, $\mathrm{pH}$, percentage pond shading and altitude) and aquatic macroinvertebrate

226 communities at a family and species level between urban and non-urban ponds were examined.

227 All analyses were carried out in the R environment (R Development Core Team, 2013). Prior to

228 statistical analysis the data was screened to remove any missing values. Estimated gamma

229 diversity was calculated using Chao2 estimator in the vegan package in R (Oksanen et al., 2015).

230 Mann-Whitney U tests were used to test for differences in alpha diversity (family and species

231 richness) between urban and non-urban ponds. To account for the fact that there were different

232 numbers of urban and non-urban sites, taxon accumulation curves were constructed by

233 randomized resampling of sites without replacement using the specaccum function in vegan with

2341,000 permutations per sample size. From these curves the mean number of families and species

235 in each simulated group of sites and the standard error were calculated. Variability between 
236 urban and non-urban ponds in the environmental variables was tested using Mann-Whitney U

237 tests. Differences between environmental variables and faunal community composition in urban

238 and non-urban ponds were visualized using Non-Metric Multidimensional Scaling (NMDS) with

239 the metaMDS function in the vegan package and were examined statistically using a

240 'Permutational Analysis of Variance' (PERMANOVA). Bray-Curtis dissimilarity was used to

241 analyse the macroinvertebrate data and Euclidean distance used for the environmental data.

242 Homogeneity of multivariate dispersions between the environmental data and macroinvertebrate

243 communities from urban and non-urban ponds were calculated using the betadisper function in

244 vegan and compared using an ANOVA. To identify indicator taxa of ephemeral and perennial ponds

245 Indicator Value analysis (IndVal: Dufrêne \& Legendre 1997) was undertaken. To test the spatial

246 patterns of community structure in urban and non-urban ponds, a Mantel correlogram was

247 constructed between the aquatic macroinvertebrate distance matrix (Euclidean) and the

248 geographical distance for urban and non-urban ponds using the mantel.correlog function in the

249 vegan package in R. Breaks among distance classes in the Mantel correlogram were defined in

$25050 \mathrm{~km}$ intervals. The Mantel correlogram enables the identification of changes in the strength of

251 correlation between faunal distance matrices and geographic distance matrices at different spatial

252 scales (Rangel et al., 2010).

254 The relationship between macroinvertebrate assemblages and environmental variables $(\mathrm{pH}$, 255 percentage coverage of emergent macrophytes, percentage pond shading, altitude, location 256 within urban area, and pond area) was examined using redundancy analysis (RDA) in the vegan 257 package. A stepwise selection procedure (forward and backward selection) was employed to 258 select the best model and environmental variables that significantly $(\mathrm{p}<0.05)$ explained the 
259 variance in pond macroinvertebrate assemblages using the ordistep function in vegan, which

260 uses permutation-based significance tests (999 permutations).

262 Results

263

Urban and non-urban pond environmental characteristics

264 Comparisons between specific environmental variables in urban and non-urban ponds that are

265 thought to influence diversity and composition showed that altitude $(\mathrm{W}=108179.5 \mathrm{p}<0.01$;

266 Figure 2A) and pond shading (W=92965.5 $\mathrm{p}<0.01$; Figure $2 \mathrm{~B}$ ) were significantly higher for

267 urban ponds (mean altitude: $85.9 \pm 3.7$ masl; mean shading $22.89 \pm 1.84 \%$ ) than non-urban

268 ponds (mean altitude: $78.2 \pm 2.8$ masl; mean shading $19.61 \pm 0.95 \%$ ), but the absolute

269 differences between the pond types are small enough that they may be biologically insignificant .

$270 \mathrm{pH}$ was significantly higher for urban ponds (mean $7.44 \pm 0.06 \mathrm{SE}$ ) compared to non-urban ponds

$271(7.37 \pm 0.16 ; \mathrm{W}=37024 \mathrm{p}<0.05 ;$ Figure $2 \mathrm{C})$ although in both pond types $\mathrm{pH}$ was close to neutral.

272 Non-urban ponds demonstrated a greater variability in $\mathrm{pH}$ compared to urban ponds. A total of

$27313 \%$ of non-urban ponds ( 66 ponds) recorded a $\mathrm{pH}<6.5$, whilst only $4 \%$ of urban ponds (10

274 urban ponds) recorded a $\mathrm{pH}<6.5$. In addition, pond area was on average $43 \%$ larger in non-urban

275 ponds $\left(2207 \pm 139 \mathrm{~m}^{2}\right)$ compared to urban ponds $\left(1546 \pm 171 \mathrm{~m}^{2} ; \mathrm{W}=75154.5 \mathrm{p}<0.01\right.$; Figure 2D).

276 Emergent macrophyte coverage was significantly higher in non-urban ponds $(33.10 \pm 1.08 \%)$

277 compared to urban ponds $(27.77 \pm 1.87 \%$; $\mathrm{W}=81695 \mathrm{p}<0.01$; Figure $2 \mathrm{E})$ although the mean

278 difference was $<5 \%$.

279

280

Aquatic macroinvertebrate diversity 
281 Family-level gamma diversity was similar between urban (observed 96 families, Figure 3A) and 282 non-urban ponds (observed 103 families, Figure 3B), and the Chao2 estimator produced results taking into account sample size that were not statistically different across the two pond types

284 (urban: 108.2, 95\% CI: 91.4-125.0 families; non-urban: 107.5, 95\% CI: 99.7-115.3 families). At

285

286

287

288

289

290

291

292

293

294

295

296

297

298

299

300

301

302

303

an alpha scale urban ponds (median richness $=13$, range $=2-44$ ) supported significantly greater macroinvertebrate family richness compared to non-urban ponds (median richness $=12$, range $=$ 2-38; $\mathrm{W}=20430.5 \mathrm{p}<0.01)$ although median richness values were very similar between the pond types. Species-level gamma diversity was lower in urban (observed 403 species) than non-urban sites (observed 473 species), but the Chao 2 estimator showed that there was no significant difference after controlling for the number of sites (urban: 496.6, 95\%CI: 445.6-547.7 species; non-urban: 572.9, 95\%CI: 520.2-625.7 species). No significant difference in alpha diversity between macroinvertebrate species was recorded between urban (median: 28) and non-urban ponds (median 26; $\mathrm{W}=17310 \mathrm{p}=0.507)$.

Urban ponds demonstrated a greater variability in alpha diversity among individual ponds at a family and species level (Figure 3C, 3D). A total of 25 urban ponds (11\% of total urban pond number) supported $>25$ macroinvertebrate families, whilst only 9 non-urban ponds $(1.5 \%$ of total non-urban pond number) supported macroinvertebrate communities with $>25$ families. In addition, the greatest number of invertebrate families recorded was from an urban pond (46 taxa) and 5 of the 6 ponds with the greatest macroinvertebrate family richness were located in urban environments. Only two families of macroinvertebrates were statistically associated with non-urban ponds (one family of Plecoptera, one family of Ephemeroptera), while 20 families were identified as indicator taxa for urban ponds, including seven families of Diptera. Strongest associations for families are 
presented in Table 2 (see Supplementary Material Table S10 for the full list of statistically significant family indicator values, and Supplementary Table S11 for significant indicator values of macroinvertebrate species).

When non-urban ponds designated as degraded were removed and the macroinvertebrate diversity in the remaining ponds was compared to urban ponds, alpha diversity was significantly greater in urban ponds (median: $13 ; \mathrm{W}=18057 \mathrm{p}<0.01$ ) than the higher quality non-urban ponds

311 (median: 12) at a family level, although mean and median richness values were similar between

312 the pond types (see Supplementary Information Part 2). There was no significant difference in 313 alpha diversity $(\mathrm{W}=14653.5 \mathrm{p}=0.358)$ at the species level between urban ponds (median: 28$)$ and 314 higher quality non-urban ponds (median: 25). Estimated gamma diversity for higher quality non315 urban ponds at a family (98.7) and species scale (575.1) was marginally higher compared to 316 gamma diversity when all non-urban ponds were considered.

318 Chironomidae, Tipulidae, Crangonyctidae and Oligochaeta had a greater frequency of occurrence in urban ponds, whilst Gyrinidae, Hydrophilidae and Notonectidae displayed a 320 greater occurrence in non-urban ponds (Figure 4; for complete data see Tables S8 and S9 for 321 family and species level prevalence, respectively). Macroinvertebrate families that score highly 322 within biological monitoring surveys of ponds and other waterbodies (e.g., PSYM and BMWP) 323 such as Phryganeidae, Leptoceridae, Libellulidae and Aeshnidae occurred at similar frequencies 324 in the urban and non-urban ponds (Figure 4). Crangonyctidae were present in $49.0 \%$ of urban 325 ponds and only $29.0 \%$ of non-urban ponds. All specimens of this family from the species-level 326 dataset were the North American invasive Crangonyx pseudogracilis. A similar pattern is also 
327 seen in the species-level dataset with the invasive New Zealand mud snail, Potamopyrgus

328 antipodarum, being found in $21.3 \%$ of urban ponds and $9.5 \%$ of non-urban ponds.

\section{Community Heterogeneity}

330 Multivariate dispersion for environmental characteristics were significantly lower in non-urban 331 ponds (median distance: 1116) than urban ponds (median distance: $1978 ; \mathrm{F}=5.774 \mathrm{p}<0.05$,

332 Figure 5A). PERMANOVA showed that there was a small but significant difference between 333 environmental characteristics $\left(\mathrm{R}^{2}=0.03 \mathrm{p}<0.001\right)$ and faunal communities at a family $\left(\mathrm{R}^{2}=0.09\right.$ $334 \mathrm{p}<0.001)$ and species level $\left(\mathrm{R}^{2}=0.03 \mathrm{p}<0.001\right)$. A relatively clear distinction between aquatic 335 macroinvertebrate community composition in urban and non-urban ponds was observed at the 336 family and species level within the NMDS ordination (Figure 5B, C). Among faunal 337 communities, multivariate dispersion was significantly higher at the family (median distance 338 urban: 0.451 , non-urban: $0.406 ; \mathrm{F}=27.584 \mathrm{p}<0.01$ ) and species scale (median distance - urban: 339 0.579, non-urban: 0.550; $\mathrm{F}=17.626 \mathrm{p}<0.01$ ) for urban ponds compared to non-urban ponds.

341 There was significant positive spatial autocorrelation for urban $(r=0.31 \mathrm{p}<0.01)$ and non-urban 342 ponds $(r=0.17 \mathrm{p}<0.01)$ at the family level for the smallest distance class $(0-50 \mathrm{~km})$, indicating 343 that those ponds in close geographical proximity have similar macroinvertebrate community 344 compositions (Figure 6A). At middle distance classes (distance class three: 100-150 km) urban 345 and non-urban ponds demonstrated a significant negative Mantel spatial autocorrelation, 346 although this effect was weak for non-urban ponds (urban: $r=-0.18 \mathrm{p}<0.01$, non-urban: $r=-0.05$ $347 \mathrm{p}<0.01)$ (Figure 6A). At larger distances spatial autocorrelation declined in strength for urban 348 and non-urban ponds. The same analyses carried out on species-level data showed similar spatial 
349 patterns, but with stronger positive correlation at shorter distances $(0-50 \mathrm{~km}$, urban: $\mathrm{r}=0.45$,

$350 \mathrm{p}<0.01$; non-urban: $\mathrm{r}=0.27, \mathrm{p}<0.01)$ and stronger negative correlation at middle distances $(100$ -

351 150km, urban: $r=-0.29, \mathrm{p}<0.01$; non-urban: $\mathrm{r}=-0.08, \mathrm{p}<0.01$; Figure $6 \mathrm{~B}$ ).

Macroinvertebrate - environment relationships

354 Redundancy Analysis (RDA) of the pond macroinvertebrate family community data and

355 environmental parameters highlighted clear differences between urban and non-urban ponds

356 (Figure 7A). The RDA axes were highly significant $\left(\mathrm{F}=3.06 \mathrm{p}<0.001\right.$, Adjusted $\left.\mathrm{R}^{2}=0.02\right)$,

357 explaining $3.8 \%$ of the variation in family assemblage on all constrained axes (see

358 Supplementary Information Table S4). Stepwise selection of environmental parameters identified

359 four significant physicochemical variables correlated with the first two RDA axes: altitude, 360 emergent macrophytes (all $\mathrm{p}<0.05)$, surface area and location within urban area (both $\mathrm{p}<0.01)$

361 (Figure 7A). RDA indicated that urban and non-urban pond invertebrate communities were 362 separated on the first and second axes along gradients associated with pond surface area and 363 emergent macrophyte cover/their location within the urban landscape (Figure 7A). Non-urban 364 ponds were characterized by a greater pond area and emergent macrophyte cover, whilst urban 365 ponds were associated with smaller surface areas and less emergent macrophytes (Figure 7). 366 RDA of pond macroinvertebrate species community data showed similar patterns: urban and 367 non-urban ponds were strongly separated along the first RDA axis, with significant effects of 368 urbanisation, pond area, altitude, and shading on community structure (Figure 7B). However, in 369 both RDA analyses the explanatory power of the models was very low (see Supplementary 370 Information Table S4). 


\section{Discussion}

\section{Urban freshwater diversity}

374 This is the first study to provide a large scale, inter-city approach to test the biological response

375 of entire pond macroinvertebrate communities to urbanization. The results provide a contrast

376 with previous work on terrestrial and lotic habitats which has shown greater fragmentation,

377 reduction in habitat quality (e.g., pollution/contaminant build up), alterations to biogeochemical

378 cycles, higher air surface temperatures, increased disturbance frequencies, proliferation of non-

379 native taxa, biotic homogenization and an overall decline in biological richness in urban areas

380 (e.g., McKinney, 2002; McKinney, 2006; Grimm et al., 2008). The ecological consequences of

381 urbanization for ponds do not appear to follow the same patterns identified elsewhere for

382 terrestrial habitats.

384 Urban ponds and non-urban ponds support similar alpha diversity of aquatic macroinvertebrates

385 at a family and species level (reject hypothesis 1) and estimated gamma diversity was similar at a

386 family level, although non-urban ponds recorded higher estimated gamma diversity at a species

387 scale. These findings are consistent with a recent study of terrestrial invertebrates that showed

388 comparable levels of diversity of particular indicator groups inhabiting birch trees (Betula

389 pendula) between urban and agricultural areas (Turrini and Knop, 2015). However, an analysis

390 of the same dataset showed a homogenization of arboreal invertebrates within urban areas (Knop,

391 2016), consistent with other terrestrial ecosystem studies (McKinney, 2008) but not with our data

392 for freshwater macroinvertebrates. The lack of agreement in ecological patterns between ponds

393 (which, in this study, show similar patterns of diversity across urban boundaries) and

394 lotic/terrestrial habitats (which tend to show reduced faunal richness with increasing urbanisation) 
395 in cities may reflect the ability of pond communities to recover relatively quickly from

396 temporary anthropogenic disturbance (Thornhill, 2013). This resilience is supported by the high

397 dispersal abilities of many semi-aquatic invertebrates (Goertzen \& Suhling, 2015). Despite

398 commonly occurring in clusters, ponds are discrete habitats with small catchment areas (Davies

399 et al., 2008) and disturbance in one pond or its catchment has little impact on others in the

400 network cluster, whilst a single disturbance event in, for example, a river system would impact

401 an entire reach (Thornhill, 2013). Aside from rare taxa, there were few families that showed a

402 different prevalence between urban and non-urban ponds, including indicator taxa with high

403 BMWP scores (indicative of high water quality). However, there was also a higher prevalence of

404 Oligochaeta and Chironomidae in urban ponds which is consistent with historical disturbance

405 and subsequent recolonization by disturbance tolerant taxa, and higher prevalence of the invasive

406 C. pseudogracilis and $P$. antipodarum in urban ponds supports previous findings that urban

407 ecosystems favour the establishment of invasive species (Shochat et al., 2010).

409 We propose two potential explanations, which are not mutually exclusive, for the similarity

410 between urban and non-urban pond biodiversity. First, it has been estimated that $80 \%$ of ponds in

411 the wider UK landscape are in a degraded state (Williams et al., 2010). Hence non-urban ponds

412 and urban ponds may be suffering from external pressures and mismanagement leading to the

413 similar alpha diversities recorded. With both pond types in degraded states the biodiversity value

414 of urban ponds must be treated with caution, as their richness is compared to similar degraded

415 non-urban ponds. However, our secondary analysis demonstrated that urban ponds still show

416 comparable biodiversity to higher quality, non-degraded non-urban ponds. Research examining

417 the diversity of high-quality urban and non-urban ponds is required to fully quantify the 
418 biodiversity value of urban ponds. Second, intensive management in cities may actually promote

419 biodiversity. Whilst many ponds in non-urban areas (e.g., agricultural land) are left unmanaged,

420 neglected, and at late successional stages (Hassall et al., 2012; Sayer et al., 2012), ponds in urban

421 areas are often managed (primarily for purposes other than biodiversity) and a wide-range of

422 successional stages are maintained. Furthermore, in many cases local residents (e.g., pond

423 warden schemes) monitor and manage large numbers of urban ponds for the benefit of ecological

424 communities, improving their habitat/water quality and promoting high biological richness

425 (Boothby, 1995; Hill et al., 2015). Results from the present study show that urban areas have the

426 potential to become reservoirs of freshwater biodiversity rather than "ecological deserts", which

427 incorporate a wide range of aquatic habitats including ponds, canals, urban reservoirs and

428 wetlands (Hassall \& Anderson, 2015). However, it should be noted that diversity was highly

429 variable in this study at both the family and species level of taxonomic resolution and previous

430 research has demonstrated that some urban ponds can be of low ecological quality if

431 anthropogenic stressors such as eutrophication are allowed to persist (Noble \& Hassall, 2014).

433 Urban ponds were also characterized by contrasting values of some environmental parameters to 434 non-urban ponds. As expected, urban ponds were smaller than non-urban ponds reflecting the 435 high level of competition and the economic value of urban land. Lower emergent macrophyte 436 coverage was recorded in urban ponds compared to non-urban ponds which reflects their primary 437 function for flood water storage/water treatment and the management practices undertaken to 438 achieve this (Le Viol et al., 2009). Reduced emergent macrophyte cover in urban areas may also 439 be the result of public perceptions of pond attractiveness (clean, open water and surrounding 440 vegetation mown; Nassauer, 2004) which pond amenity managers aim to replicate, or other 
441 management practices for amenity purposes such as angling or boating (Wood et al., 2001).

442 Urban ponds were significantly more shaded than non-urban ponds, which is most likely the

443 result of urban ponds location within high density, built environments providing significant

444 additional artificial shading to that provided by trees. In addition, reduced shading of non-urban

445 ponds may be because many non-urban ponds were located in landscapes typically free of

446 shading (trees) including wetland meadows and the low numbers of trees in British agricultural

447 landscapes where many non-urban ponds are situated (however high levels of pond shading from

448 trees has been recorded in some UK agricultural areas: Sayer et al., 2012).

\section{Community heterogeneity}

451 Small but significant differences in faunal communities (family and species) were observed

452 between urban and non-urban ponds in this study (reject hypothesis 2). Differences (albeit subtle)

453 in community composition found in the present study contrast with the findings of Hassall and

454 Anderson (2015) and Le Viol et al. (2009) and suggest that at greater spatial scales urban ponds

455 contribute as much to the regional biodiversity pool as non-urban ponds. The higher community

456 dissimilarity among urban ponds may reflect the different levels of disturbance and diverse

457 management practices (reflecting their primary function e.g., flood alleviation, biodiversity,

458 amenity), as well as general pond characteristics such as small catchments which result in highly

459 heterogeneous environmental conditions (greater environmental multivariate distances than non-

460 urban ponds) even in ponds that are in close proximity (Davies et al., 2008). 
462 Significant positive spatial autocorrelation at the smallest distance class and significant negative

463 spatial autocorrelation at medium distances suggest that: 1) ponds within individual cities have

464 similar communities which reflect similar city-region environmental characteristics; and 2)

465 ponds at greater spatial distances from one another in different cities have increasingly dissimilar

466 communities reflecting the high variability in environmental (Heino \& Alahuhta, 2015) and

467 historical factors (Baselga, 2008; Heino \& Alahuhta, 2015) among cities. Spatial patterns of

468 management may influence geographical variation in community structure to a greater extent

469 than landscape connectivity, making it difficult to evaluate our third hypothesis. However, we

470 demonstrate stronger spatial structuring of urban communities at finer spatial scales, which

471 would be expected under lower connectivity. Greater connectivity in non-urban landscapes

472 enhances species movement leading to weaker spatial structuring at finer spatial scales in non-

473 urban ponds. Hence our observations support our third hypothesis, but further work is needed to

474 evaluate the consequences of spatial patterns for management. Historically, urban environments

475 were highly degraded (physically, chemically and biologically) but significant improvements to

476 urban freshwater quality have been achieved in recent decades despite urban sprawl and

477 intensification (Vaughan \& Ormerod, 2012). Therefore, it is possible that cities are still being

478 recolonized by aquatic taxa from different regional species pools using different dispersal routes, 479 creating a dynamic pattern of communities.

481 Conservation implications

482 Urban ponds support relatively high alpha and gamma diversity comparable to non-urban ponds.

483 A lack of monitoring of urban freshwaters (particularly ponds that are excluded from the EU

484 Water Framework Directive) may be hiding considerably more diversity such that urban planners 
485 fail to identify high biodiversity sites (Hassall, 2014). There is a need for a concerted,

486 comparative, empirical approach to freshwater management that incorporates biodiversity as

487 well as other ecosystem services alongside social and political considerations. Fundamental to

488 the conservation of ponds is an integrated landscape approach that recognizes the need for

489 networks of ponds (Boothby, 1997). Hence the prioritization of ponds for conservation will need

490 to take into account their location relative to other sites, requiring a complementary approach

491 that creates new habitats, improves degraded habitats, and conserves those habitats that have

492 already achieved good quality. Changes in the management of ponds more generally has led to

493 change in the environmental conditions within and around these habitats, such as the reduction in

494 riparian tree management around agricultural ponds which has consequences for light, oxygen,

495 and temperature (Sayer et al., 2013). Urban ponds are well suited to biodiversity enhancement as

496 many are sites of high diversity (Hassall, 2014) and even small changes to current management

497 strategies in urban freshwaters (e.g., the planting of native macrophytes in amenity ponds; Hill et

$498 a l ., 2015)$ are likely to significantly augment biodiversity in urban landscapes. Cities are highly

499 complex, multifunctional landscapes designed primarily for anthropogenic use yet they still

500 support considerable aquatic diversity and represent scientifically and ecologically important

501 habitats.

\section{Acknowledgements}

504 The authors would like to thank the various organizations who provided resources for the

505 datasets included in this study: the EU Life Program funded the PondLife Project. RB would like

506 to thank the Carnegie Trust for the Universities of Scotland. MH would like to acknowledge

507 Leicestershire County Council and the private land owners that granted access to their land. $\mathrm{CH}$ 
508 is grateful for support from a Marie Curie International Incoming Fellowship within the 7th

509 European Community Framework Programme. DG would like to thank Halton Borough Council

510 for support and access to pond sites and IT is grateful for the support from the Natural

511 Environment Research Council and The James Hutton Institute. 


\section{References}

513 Baselga, A. (2008) Determinants of species richness, endemism and turnover in European

514 longhorn beetles. Ecography, 31, 263-271.

515 Biggs, J., Fox, G., Whitfield, M. and Williams, P. (1998). A guide to the methods of the National 516 Pond Survey, Pond Action: Oxford.

517 Biggs J, Williams P, Whitfield M, Nicolet P, and Weatherby A. (2005) 15 years of pond 518 assessment in Britain: results and lessons learned from the work of Pond Conservation. Aquatic 519 Conservation: Marine and Freshwater Ecosystems, 15, 693-714.

520 Boothby, J. (1997) Pond conservation: towards a delineation of pondscape. Aquatic 521 Conservation: Marine and Freshwater Ecosystems, 7, 127-132.

522 Boothby, J., Hull, A. P. and Jeffreys, D. A. (1995) Sustaining a threatened landscape: farmland 523 ponds in Cheshire. Journal of Environmental Planning and Management, 38, 561-568.

524 Briers, R. A. (2014) Invertebrate communities and environmental conditions in a series of urban 525 drainage ponds in Eastern Scotland: implications for biodiversity and conservation value of 526 SUDS. Clean - Soil, Air, Water, 42, 193-200.

527 Commonwealth of Australia. 2007. Water Act 2007.

528 Dallimer, M., Tang, Z., Bibby, P. R., Brindley, P., Gaston, K. J. and Davies, Z. G. (2011)

529 Temporal changes in green space in a highly urbanized region. Biology Letters, 7, 763-766.

530 Davies, B, R., Biggs, J., Williams, P., Whitfield, M., Nicolet, P., Sear, D., Bray, S. and Maund, S.

531 (2008) Comparative biodiversity of aquatic habitats in the European agricultural landscape.

532 Agriculture, Ecosystems and Environment, 125, 1-8. 
Dufrêne, M. and P. Legendre. 1997. Species assemblages and indicator species: The need for a flexible

534 asymmetrical approach. Ecological Monographs 67: 345-366.

535 EC (2000) Directive 2000/60/EC of the European Parliament and of the Council of 23 October

5362000 establishing a framework for Community action in the field of water policy, 22/12/2000.

537 Official Journal 327/1: 1-73.

538 Environment Agency and Ponds Conservation Trust. (2002) A guide to monitoring the 539 ecological quality of ponds and canals using PSYM. PCTPR, Oxford.

540 Fitzhugh, T. W. and Richter, B. D. (2004) Quenching urban thirst: growing cities and their 541 impacts on freshwater ecosystems. BioScience, 54, 741-754.

542 Gledhill, D. G., James, P. and Davies, D. H. (2008) Pond density as a determinant of aquatic 543 species richness in an urban landscape. Landscape Ecology, 23, 1219-1230.

544 Goertzen, D. and Suhling, F. (2015) Central European cities maintain substantial dragonfly 545 species richness - a chance for biodiversity conservation. Insect Conservation and Diversity, 8 , $546 \quad 238-246$

547 Grimm, N. B., Faeth, S. H., Golubiewski, N. E., Redman, C. L., Wu, J., Bai, X. and Briggs, J. M. 548 (2008) Global change and the ecology of cities. Science, 319, 756-760.

549 Hamer, A. J., Smith, P. J. and McDonnell, M. J. (2012) The importance of habitat design and 550 aquatic connectivity in amphibian use of urban stormwater retention ponds. Urban Ecosystems, $551 \quad \mathbf{1 5}, 451-471$.

552 Hassall, C. and Anderson, S. (2015) Stormwater ponds can contain comparable biodiversity to 553 unmanaged wetlands in urban areas. Hydrobiologia, 745, 137-149. 
554 Hassall, C. (2014) The ecology and biodiversity of urban ponds. Wiley Interdisciplinary

555 Reviews: Water, 1, 187-206.

556 Hassall, C., Hollinshead, J. and Hull, A. (2011) Environmental correlates of plant and

557 invertebrate species richness in ponds, Biodiversity and Conservation, 20, 3189-3222.

558 Hassall, C., Hollinshead, J. and Hull, A. (2012) Temporal dynamics of aquatic communities and 559 implications for pond conservation, Biodiversity and Conservation, 21, 829-852.

560 Heino, J. (2014) Taxonomic surrogacy, numerical resolution and responses of stream

561 macroinvertebrate communities to ecological gradients: are the inferences transferable among

562 regions? Ecological Indicators, 36, 186-194.

563 Heino, J. and Alahuhta, J. (2015) Elements of regional beetle faunas: faunal variation and 564 compositional break points along climate, land cover and geographical gradients. Journal of 565 Animal Ecology, 84, 427-441.

566 Hill, M. J. and Wood, P. J. (2014) The macroinvertebrate biodiversity and conservation value of 567 garden and field ponds along a rural - urban gradient. Fundamental and Applied Limnology, 185, $568 \quad 107-119$.

569 Hill, M. J., Mathers, K. L. and Wood, P. J. (2015) The aquatic macroinvertebrate biodiversity of 570 urban ponds in a medium sized European town (Loughborough, UK). Hydrobiologia, 760, 225571238.

572 Hitchings, S. P. and Beebee, T. J. C. (1997) Genetic substructuring as a result of barriers to gene 573 flow in urban Rana temporaria (common frog) populations: implications for biodiversity 574 conservation. Heredity, 79, 117-127. 
575 Jeanmougin, M., Leprieur, F., Lois, G. and Clergeau, P. (2014) Fine scale urbanization effects 576 Odonata species diversity in ponds of a mega city (Paris, France). Acta Oecologica, 59, 26-34.

577 Knop, E. (2016) Biotic homogenization of three insect groups due to urbanization. Global

578 Change Biology, 22: 228-236. Le Viol, I., Mocq, J. Julliard, R. and Kerbiriou, C. (2009) The

579 contribution of motorway stormwater retention ponds to the biodiversity of aquatic

580 macroinvertebrates. Biological Conservation, 142, 3163-3171.

581 McKinney, M. L. (2002) Urbanization, biodiversity and conservation. Bioscience, 52, 883-890.

582 McKinney, M. L. (2006) Urbanization as a major cause of biotic homogenization. Biological

583 Conservation, 127, 247-260.

584 McKinney, M. L. (2008) Effects of urbanization of species richness: a review of plants and 585 animals. Urban Ecosystems, 11, 161-176.

586 Monk, W. A., Wood, P. J., Hannah, D. M., Extence, C., Chadd, R. and Dunbar, M. J. (2012)

587 How does macroinvertebrate taxonomic resolution influence ecohydrological relationships in 588 riverine ecosystems. Ecohydrology, 5, 36-45.

589 Mueller, M., Pander, J. and Geist, J. (2013) Taxonomic sufficiency in freshwater ecosystems: 590 effects of taxonomic resolution, functional traits and data transformation. Freshwater Science, $591 \quad 32,762-778$.

592 Nassauer, J. I. (2004) Monitoring the success of metropolitan wetland restorations: cultural 593 sustainability and ecological function. Wetlands, 24, 756-765.

594 Noble, A. and Hassall, C. (2014) Poor ecological quality of urban ponds in northern England: 595 causes and consequences. Urban Ecosystems: 1-14. 
Oksanen, J., Blanchet, F.G., Kindt, R., Legendre, P., Minchin, P. R., O'Hara, R.B., Simpson, 597 G.L., Solymos, Stevens, H.H. and Wagner, H. 2015. Vegan: Community Ecology Package. R 598 package version 2.3-1. [Accessible at http://CRAN.R-project.org/package=vegan].

599 Pereira, M., Segurado, P. and Neves, N. (2011) Using spatial network structure in landscape 600 management and planning: A case study with pond turtles. Landscape and Urban Planning, 100, $601 \quad 67-76$.

602 Pond Life Project. (2000) A landscape worth saving: Final report of the pond biodiversity survey 603 of North West England. Pond Life Project: Liverpool.

604 R Development Core Team. (2013) R: A Language and Environment for Statistical Computing. 605 R Foundation for Statistical Computing, Vienna, Austria.

606 Rangel, T. F., Diniz-Filho, J. A. F. and Bini, L. M. (2010) SAM: a comprehensive application for 607 spatial analysis in macroecology. Ecography, 33, 46-50.

608 Roy, A. H., Rosemond, A. H., Paul, M. J., Leigh, D. S. and Wallace, J. B. 2003. Stream 609 macroinvertebrate response to catchment urbanization (Georgia, USA). Freshwater Biology, 48, $610 \quad 329-346$.

611 Sala, et al. (2000) Global biodiversity scenarios for the year 2100. Science, 287, 1770-1774.

612 Sayer, C.D., Andrews, K., Shiland, E., Edmonds, N., Edmonds-Brown, R., Patmore, I., Emson, 613 and D., Axmacher, J. (2012) The role of pond management for biodiversity conservation in an 614 agricultural landscape. Aquatic Conservation, 22, 626-638.

615 Sayer, C.D., Shilland, E., Greaves, H., Dawson, B., Patmore, I.R., Emson, E., Alderton, E., 616 Robinson, P., Andrews, K., Axmacher, J.A. and Wiik, E. (2013) Managing British ponds 617 conservation lessons from a Norfolk farm. British Wildlife, 25, 21-28. 
618 Shochat, E., Lerman, S. B., Anderies, J. M. Warren., P. S., Faeth, S. H. and Nilon, C. H. (2010)

619 Invasion, competition, and biodiversity loss in urban ecosystems. Bioscience, 60, 199-208.

620 Thornhill, I. A. G. (2013) Water quality, biodiversity and ecosystem functioning in ponds across 621 an urban land-use gradient in Birmingham, UK. PhD Thesis, University of Birmingham: UK.

622 Turrini T. and Knop, E. (2015) A landscape ecology approach identifies important drivers of 623 urban biodiversity. Global Change Biology, 21, 1652-1667.

624 UKNEA, (2011) The UK National Ecosystem Assessment Technical Report. UNEP-WCMC, 625 Cambridge.

626 United Nations, (2014) World Urbanization Prospects: the 2014 revision. United Nations: New 627 York.

628 Vaughan, I. P. and Ormerod, S. J. (2012) Large-scale, long-term trends in British river 629 macroinvertebrates. Global Change Biology, 18, 2184-2194.

630 Vilmi, A., Maaria Karjalainen, S., Nokela, T., Tolonen, T. and Heino, J. 2016. Unravelling the 631 drivers of aquatic communities using disparate organismal groups and different taxonomic 632 levels. Ecological Indicators, 60, 108-118.

633 Walsh, C. J., Roy, A. H., Feminella, J. W. and Cottingham, P. D. (2005) The urban stream 634 syndrome: current knowledge and the search for a cure. Journal of the North American 635 Benthological Society, 24, 706-723.

636 Williams, P., Biggs, J., Crowe, A., Murphy, J., Nicolet, P., Meatherby, A. and Dunbar, M. (2010) 637 Countryside survey report from 2007, Technical report No 7/07 Pond Conservation and 638 NERC/Centre for Ecology and Hydrology, Lancaster. 
639 Wood, P. J., Greenwood, M. T., Barker, S. A. and Gunn, J. (2001) The effects of amenity

640 management for angling on the conservation value of aquatic invertebrate communities in old

641 industrial mill ponds. Biological Conservation, 102, 17-29.

642 Wood, P.J., Greenwood, M. T. and Agnew, M. D. (2003) Pond biodiversity and habitat loss in 643 the UK. Area, 35, 206-216.

644 


\begin{tabular}{|c|c|c|c|c|c|}
\hline $\begin{array}{l}\text { Reference } \\
\text { Number }\end{array}$ & $\begin{array}{l}\text { Geographic } \\
\text { Scale }\end{array}$ & $\begin{array}{l}\text { Aquatic macroinvertebrate Sampling } \\
\text { Methodology }\end{array}$ & $\begin{array}{l}\text { Taxonomic } \\
\text { Resolution }\end{array}$ & Taxa Included & Reference \\
\hline 1 & $\begin{array}{l}\text { UK wide } \\
n=152\end{array}$ & $\begin{array}{l}\text { Individual ponds sampled for } 3 \text { minutes in } \\
\text { spring, summer and autumn using a sweep } \\
\text { sample technique. Sampling time was } \\
\text { divided between the mesohabitats recorded } \\
\text { in each pond. }\end{array}$ & $\begin{array}{l}\text { Species, except for } \\
\text { Oligochaeta, } \\
\text { Diptera and small } \\
\text { bivalves }\end{array}$ & $\begin{array}{l}\text { Aquatic } \\
\text { macroinvertebrates (water } \\
\text { mites, zooplankton and } \\
\text { other micro-arthropods } \\
\text { were not included) }\end{array}$ & $\begin{array}{l}\text { Biggs et al., } \\
1998\end{array}$ \\
\hline 2 & $\begin{array}{l}\text { Dunfermline, } \\
\text { Fife, Scotland } \\
\mathrm{n}=14\end{array}$ & $\begin{array}{l}\text { Individual ponds were sampled annually } \\
\text { between } 2007-2011 \text { in the summer following } \\
\text { the methods of the National Pond Survey. }\end{array}$ & $\begin{array}{l}\text { Species, except for } \\
\text { Oligochaeta, } \\
\text { Ostracoda and } \\
\text { Diptera }\end{array}$ & $\begin{array}{l}\text { Aquatic } \\
\text { macroinvertebrates }\end{array}$ & Briers, 2014 \\
\hline 3 & $\begin{array}{l}\text { Leicestershire, } \\
\text { UK } \\
\mathrm{n}=41\end{array}$ & $\begin{array}{l}\text { Individual ponds were sampled over spring, } \\
\text { summer and autumn seasons. Sampling time } \\
\text { was proportional to surface area, up to a } \\
\text { maximum of three minutes. Sampling time } \\
\text { designated to each pond was divided } \\
\text { between the mesohabitats recorded. }\end{array}$ & $\begin{array}{l}\text { Species, except for } \\
\text { Diptera, } \\
\text { Oligochaeta, } \\
\text { Hydrachnidiae and } \\
\text { Collembola }\end{array}$ & $\begin{array}{l}\text { Aquatic } \\
\text { macroinvertebrates } \\
\text { (zooplankton and other } \\
\text { micro arthropods were not } \\
\text { included) }\end{array}$ & $\begin{array}{l}\text { Hill et al., } \\
2015\end{array}$ \\
\hline 4 & $\begin{array}{l}\text { West } \\
\text { Yorkshire, UK } \\
\mathrm{n}=36\end{array}$ & $\begin{array}{l}\text { Individual ponds were sampled during the } \\
\text { summer and autumn, following the } \\
\text { guidelines of the National Pond Survey. In } \\
\text { addition, soft benthic samples were taken } \\
\text { using an Eckman Grab. }\end{array}$ & $\begin{array}{l}\text { Species, except } \\
\text { Ostracoda, } \\
\text { Copepoda and } \\
\text { Diptera }\end{array}$ & $\begin{array}{l}\text { Aquatic } \\
\text { macroinvertebrates }\end{array}$ & $\begin{array}{l}\text { Wood et al., } \\
2001\end{array}$ \\
\hline 5 & $\begin{array}{l}\text { Bradford, UK } \\
n=21\end{array}$ & $\begin{array}{l}\text { Individual ponds were sampled for } 3 \\
\text { minutes in the summer. Sampling time was } \\
\text { divided between the mesohabitats present. }\end{array}$ & Family level & $\begin{array}{l}\text { Aquatic } \\
\text { macroinvertebrates } \\
\text { (presence of fish and } \\
\text { amphibians noted) }\end{array}$ & $\begin{array}{l}\text { Noble \& } \\
\text { Hassall, } \\
2014\end{array}$ \\
\hline 6 & $\begin{array}{l}\text { Birmingham, } \\
\text { UK } \\
\mathrm{n}=30\end{array}$ & $\begin{array}{l}\text { Individual ponds were sampled for } 3 \\
\text { minutes in the spring and summer, following } \\
\text { the guidelines of the National Pond Survey. }\end{array}$ & $\begin{array}{l}\text { Species, except } \\
\text { Diptera, } \\
\text { Sphaeriidae and } \\
\text { Oligochaeta }\end{array}$ & $\begin{array}{l}\text { Aquatic } \\
\text { macroinvertebrates }\end{array}$ & $\begin{array}{l}\text { Thornhill, } \\
2013\end{array}$ \\
\hline
\end{tabular}


Individual ponds were sampled twice per year (summer and autumn) for 2 years. Samples were taken from all available mesohabitats using a standard pond net until no new species were recorded.

Samples were taken from all available

North West England $\mathrm{n}=425$

\section{Leeds, UK} $\mathrm{n}=11$

\section{UK wide} $\mathrm{n}=169$

\section{Leeds, UK} $\mathrm{n}=10$ mesohabitats using a standard pond net until no new species were recorded. Logs and debris was lifted to look for macroinvertebrates located beneath.

Individual ponds were sampled for 3 minutes in the summer. Sampling time was divided between the mesohabitats present.

Individual ponds were sampled for 3 minutes in spring, summer and autumn using a sweep sample technique. Sampling time was divided between the mesohabitats recorded in each pond.

Individual ponds sampled for 3 minutes in spring, summer and autumn using a sweep sample technique. Sampling time was divided between the mesohabitats recorded in each pond.

Individual ponds were sampled for 3 minutes in the summer. Sampling time was divided between the mesohabitats present.

\section{Aquatic}

Species

Species except

Diptera, and

Oligochaeta which

were not

examined.

Family level

Species, except for Oligochaeta,

Diptera and small bivalves

Species, except for Oligochaeta,

Diptera and small bivalves

\section{Family level}

macroinvertebrates,

Aquatic macrophytes, Amphibians

Aquatic

macroinvertebrates,

Aquatic macrophytes,

Amphibians

Aquatic

macroinvertebrates

Aquatic

macroinvertebrates (water mites, zooplankton and other micro-arthropods were not included)

Aquatic

macroinvertebrates (water mites, zooplankton and other micro-arthropods were not included)

Aquatic macroinvertebrates
Gledhill et al., 2008

Pond life

Project,

2000

Moyers \&

Hassall unpub.

FHT

Realising

Our

Potential

Award

dataset

unpub.

FHT

Temporary

Ponds

dataset

unpub.

Barber \&

Hassall

unpub. 
646 Table 2 - Aquatic macroinvertebrate families identified as indicator taxa for urban (top 6 out of 20) and

647 non-urban ponds (the only two significant values) based on indicator value analysis (see text for details).

$648 *=\mathrm{p}<0.05, * *=\mathrm{P}<0.01$

\begin{tabular}{llll}
\hline Non-Urban ponds & Stat & Urban ponds & Stat \\
\hline Nemouridae** $^{*}$ & 0.34 & Chironomidae** & 0.72 \\
Heptageniidae* $^{0.20}$ & Oligochaeta** & 0.69 \\
& & Crangonyctidae** & 0.63 \\
& & Sphaeriidae** & 0.51 \\
& & Certaopogonidae** & 0.48 \\
& & Dixidae** & 0.46 \\
\hline
\end{tabular}

649

650 


\section{Figure legends}

652 Figure 1 - Map of Great Britain showing the locations of the surveyed urban (light grey circles)

653 and non-urban (dark grey circles) ponds.

654 Figure 2: Comparison of environmental values between non-urban and urban ponds for (a)

655 altitude, (b) shading, (c) $\mathrm{pH}$, (d) pond area, and (e) emergent plant cover. Each dot represents a

656 site, and dots are offset to illustrate multiple sites at the same value.

657 Figure 3: Species accumulation curves of family richness (a) and species richness (b): grey area

658 with black line $=$ urban ponds, black area with white line $=$ non-urban ponds, and median

659 macroinvertebrate family richness (c) and species richness (d) for urban and non-urban ponds.

660 Boxes show $25^{\text {th }}, 50^{\text {th }}$, and $75^{\text {th }}$ percentiles and whiskers show $5^{\text {th }}$ and $95^{\text {th }}$ percentiles.

661 Figure 4: Prevalence of aquatic macroinvertebrate families (a) and species (b) in urban and non-

662 urban ponds. Macroinvertebrate families listed in text are presented as grey circles and have been 663 named (see Table S8 and Table S9 for raw data).

664 Figure 5: Non-metric multidimensional scaling plots of variation in (a) environmental variables,

665 (b) aquatic macroinvertebrate families and (c) aquatic macroinvertebrate species from urban and 666 non-urban ponds (light grey symbols = urban ponds and dark grey symbols = non-urban ponds).

667 Figure 6 - Mantel correlogram for presence-absence macroinvertebrate data at (a) family and (b)

668 species level along $50 \mathrm{~km}$ distance intervals (distances between pond study sites). Triangles $=$ 669 non-urban sites, circles = urban sites. Filled symbols indicate statistically significant Mantel

670 correlations.

671 Figure 7 - RDA site plots of (a) family-level and (b) species-level macroinvertebrate

672 communities recorded from the urban and non-urban pond types studied across the UK. Only 
673 significant environmental parameters are presented. Dark grey circles = urban ponds, light grey 674 circles $=$ non-urban ponds. 


\section{Supplementary information}

In this document we present additional data and analyses. Part 1 demonstrates the differences among three different methods to describe urban ponds. Part 2 provides the same analyses as in the main paper but for a subset of sites that exclude sites recorded as "degraded". Part 3 contains the tables of species prevalence across urban and non-urban ponds. 


\section{Part 1: Definitions of "urban ponds"}

In the main text we characterise urban ponds as those which are located within developed urban land use areas (DLUAs), areas of urban land demarcated by the UK Ordnance Survey mapping authority. However, we acknowledge that there are alternative methods to classify urban ponds and we provide a comparison with two such measures below:

1. Distance to urban area: The distance was calculated between each pond and the nearest urban land use area, where ponds within urban land use areas were allocated a value of 0 $\mathrm{km}$.

2. Urban landcover in a $1 \mathrm{~km}$ buffer: Each pond was buffered to a distance of $1 \mathrm{~km}$ (a buffer area of $3.14 \mathrm{~km}^{2}$ ) and the proportion of that buffer containing urban land use was calculated.

Figure $\mathrm{S} 1$ shows the relationship between a binary categorisation of sites (as used in the main text) and these two alternative measures of urbanness. We further define additional threshold values for "urbanness" based on the distance from urban areas and the percentage of the $1 \mathrm{~km}$ buffer containing urban land (Table S1). To test for the sensitivity of our findings to these different definitions of "urban", we carried out supplementary sensitivity analysis which is presented below for alpha diversity and gamma diversity.
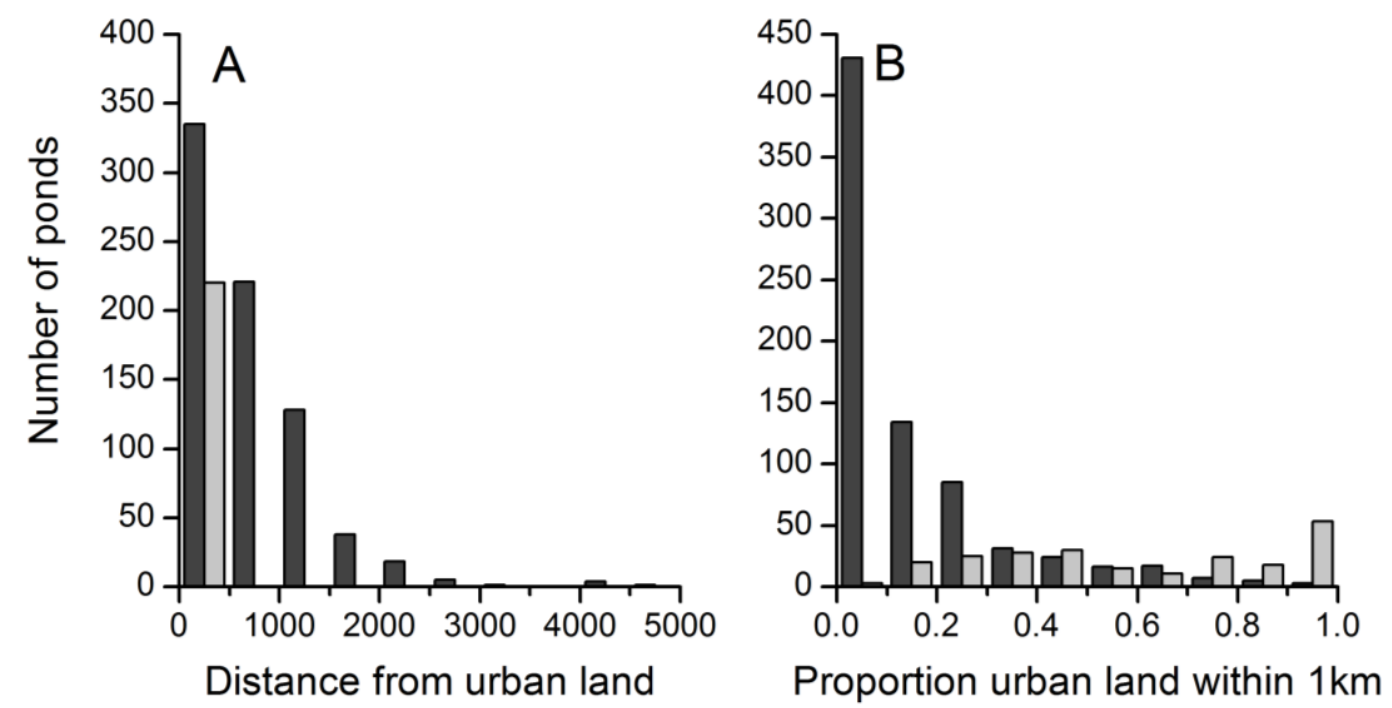

Figure S1: Comparison of three measures of pond classification. (A) shows the distance of each pond from the edge of a developed land use area (DLUA, see main text for details) for "urban" (light grey bar) and "non-urban" (dark grey bar) ponds as classified by their presence inside or outside of the DLUAs. (B) shows the proportion of urban land within a circular buffer of radius $1 \mathrm{~km}$ for the urban and non-urban ponds. Note that the urban ponds shown in (A) are all $0 \mathrm{~km}$ from urban land as they lie within the DLUAs. 
Table S1: Threshold values for the definition of a pond as "urban", with sample sizes of urban and non-urban pond derived for each threshold.

\begin{tabular}{|l|l|c|c|c|c|}
\hline & & \multicolumn{2}{|c|}{ Species } & \multicolumn{2}{c|}{ Family } \\
\hline Assumption & Definitions of urban pond & Urban & Non-urban & Urban & Non-urban \\
\hline 1 & Within urban land use area & 574 & 203 & 607 & 229 \\
\hline 2 & $<500 \mathrm{~m}$ from urban land use area & 448 & 329 & 503 & 333 \\
\hline 3 & $<1000 \mathrm{~m}$ from urban land use area & 628 & 149 & 686 & 150 \\
\hline 4 & $100 \%$ urban land cover in 1 km buffer & 23 & 754 & 28 & 808 \\
\hline 5 & $>80 \%$ urban land cover in 1 km buffer & 63 & 714 & 81 & 755 \\
\hline 6 & $>60 \%$ urban land cover in 1 km buffer & 115 & 662 & 140 & 696 \\
\hline 7 & $>40 \%$ urban land cover in 1 km buffer & 186 & 591 & 230 & 606 \\
\hline 8 & $>20 \%$ urban land cover in 1 km buffer & 328 & 449 & 379 & 457 \\
\hline
\end{tabular}

\section{Alpha diversity}

Methods: Mann-Whitney U tests were used to test for a difference in recorded taxon number (families and species) in urban and non-urban ponds under several definitions. Spearman rank correlations were used to test for an association between alpha diversity and (i) the distance to the nearest urban land use area, and (ii) the area of

Results: There were no significant correlations between alpha diversity at the species level and the distance to urban area $(\mathrm{rho}=0.053, \mathrm{p}=0.138)$ or the percentage of the $1 \mathrm{~km}$ containing urban land use area $(\mathrm{rho}=-0.051, \mathrm{p}=0.156)$, or between alpha diversity at a family level and the distance to urban area $(\mathrm{rho}=-0.018, \mathrm{p}=0.594)$ or the percentage of the $1 \mathrm{~km}$ containing urban land use area $(\mathrm{rho}=0.023, \mathrm{p}=0.511)$. When ponds were classified as either urban or non-urban according to the criteria in Table S1, there were only two assumptions that produced a significant difference between urban and non-urban species-level richness and both results were only marginally significant $(p>0.025$; Table S2). One of these assumption (4) resulted in only 23 urban ponds compared against 754 non-urban ponds. None of the assumptions produced a significant difference in family-level richness.

Table S2: Sensitivity analysis showing the variation in alpha diversity in ponds categorised as "urban" or "non-urban" using different thresholds (see Table S1 for definitions of the assumptions), with results of Mann-Whitney U-tests.

\begin{tabular}{lccccc}
\hline Taxonomic level & Assumption & Urban alpha & Non-urban alpha & $\boldsymbol{W}$ & $\boldsymbol{p}$ \\
\hline Species & 1 & 24 & 27 & 62043 & 0.169 \\
& 2 & 26 & 27 & 72544 & 0.709 \\
& 3 & 27 & 26 & 45898 & 0.719 \\
& 4 & 17 & 27 & 10996 & 0.028 \\
5 & 22 & 27 & 24548 & 0.229 \\
& 6 & 23 & 27 & 39495 & 0.520 \\
& 7 & 23 & 27 & 60841 & 0.028 \\
Family & 25 & 27 & 78276 & 0.133 \\
& & & & & \\
& 1 & 13 & 13 & 65476 & 0.196 \\
& 2 & 13 & 13 & 79710 & 0.237 \\
& 3 & 12 & 13 & 46680 & 0.075 \\
& 4 & 13 & 13 & 11716 & 0.748 \\
& 5 & 13 & 13 & 29253 & 0.521 \\
& 6 & 13 & 13 & 66038 & 0.303 \\
& 7 & 13 & 13 & 85828 & 0.717 \\
& 8 & & &
\end{tabular}




\section{Gamma diversity}

Methods: Gamma diversity was calculated for ponds classified according to the criteria in Table S1 using Chao's estimator from the specpool function in the vegan (Oskanen et al., 2007) package in $\mathrm{R}$ (R Core Team, 2015). Significant differences were evaluated using the overlap of the $95 \%$ confidence intervals associated with the estimates of taxonomic richness.

Results: There were four assumptions that led to a significant difference (lack of overlap between 95\% CIs) in species-level gamma diversity: Assumption 3 suggested a higher number of taxa in urban ponds, while Assumptions 4, 5 and 6 suggested a higher number of taxa in non-urban ponds (Table S3). In each of these cases the sample with the small number of taxa also had a far smaller number of sites $(<20 \%$ of the number of sites as in the other sample; see Table S1). Indeed, even though the Chao estimator nominally controls for sample size, the Chao value correlates strongly with sample size, suggesting that the only fair comparisons occur when sample sizes are more similar (Assumptions 1, 2, 7 and 8, Figure S2). A similar pattern is also seen in the family data, but only Assumption 4 produced a significant difference between the gamma diversity estimates.
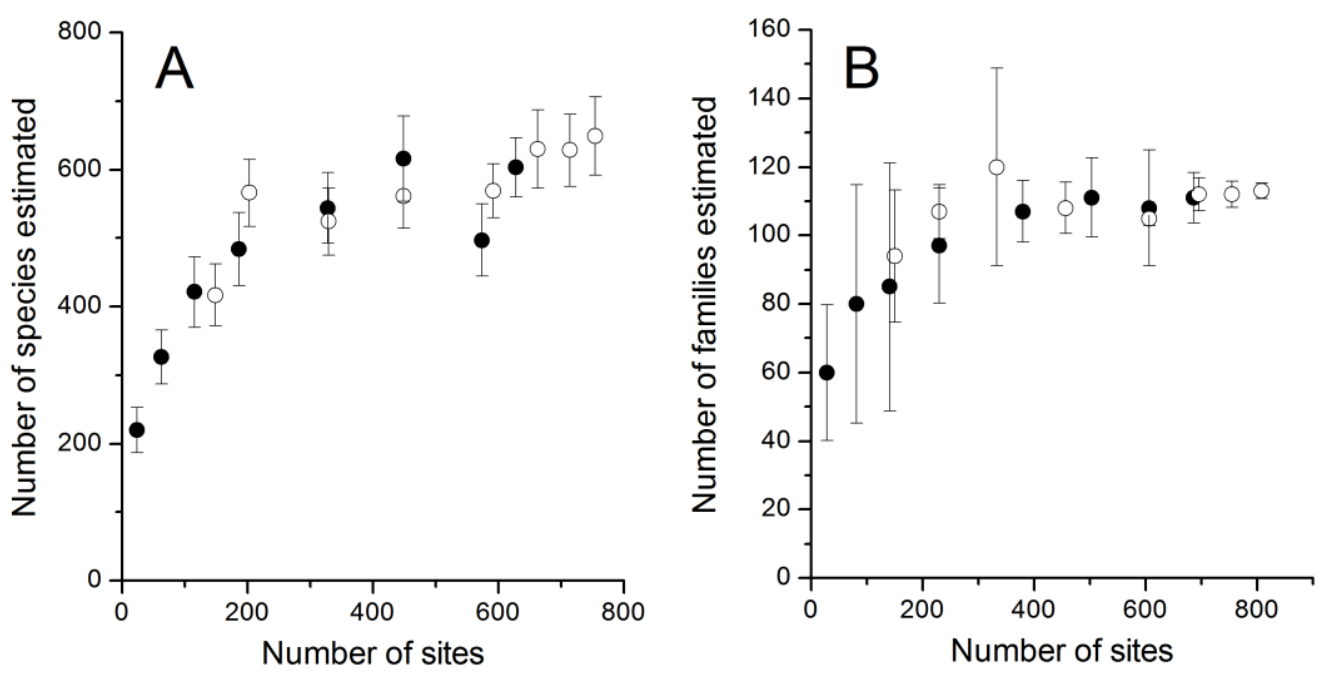

Figure S2: Chao estimates $( \pm 95 \% \mathrm{Cl})$ for the different assumptions made concerning the definition of an "urban pond". Data are shown in relation to the number of sites included within each definition (see Table S1 for details) for gamma diversity at (A) species-and (B) family-level. Filled circles are urban pond samples, open circles are non-urban pond samples. 
Table S3: Sensitivity analysis showing the variation in relative gamma diversity in ponds categorised as "urban" or "non-urban" using different thresholds (see Table S1 for definitions of the assumptions).

\begin{tabular}{lccccc}
\hline Taxonomic level & Assumption & Urban gamma & Urban SE & Non-urban gamma & Non-urban SE \\
\hline Species & 1 & 497 & 27 & 566 & 25 \\
& 2 & 616 & 32 & 524 & 25 \\
& 3 & 603 & 22 & 417 & 23 \\
& 4 & 220 & 17 & 649 & 29 \\
& 5 & 326 & 20 & 628 & 27 \\
& 6 & 421 & 26 & 630 & 29 \\
Family & 7 & 484 & 27 & 569 & 20 \\
& 8 & 544 & 26 & 561 & \\
& & & & & 4.0 \\
& 1 & 108 & 8.6 & 107 & 14.7 \\
& 2 & 111 & 5.9 & 120 & 1.2 \\
& 3 & 111 & 3.8 & 94 & 2.0 \\
& 4 & 60 & 10.1 & 113 & 2.5 \\
& 5 & 80 & 17.7 & 112 & 1.1 \\
& 6 & 85 & 18.5 & 112 & 3.8 \\
\hline
\end{tabular}


Table S4 - Summary statistics for redundancy analysis of macroinvertebrate community data at (A) family-level and (B) species-level, with significant explanatory environmental parameters.

\begin{tabular}{|c|c|c|c|c|c|c|}
\hline \multicolumn{7}{|c|}{ A: Eigenvalues for constrained axes in family-level RDA } \\
\hline & RDA & RDA & RDA & RDA & RDA & RDA \\
\hline & 1 & 2 & 3 & 4 & 5 & 6 \\
\hline Eigenvalues & 0.198 & 0.056 & 0.033 & 0.018 & 0.015 & 0.006 \\
\hline Proportion Explained (\%) & 2.3 & 0.66 & 0.38 & 0.21 & 0.17 & 0.06 \\
\hline Cumulative Proportion Explained (\%) & 2.3 & 2.96 & 3.34 & 3.55 & 3.72 & 3.78 \\
\hline Adjusted $R^{2}$ & 0.02 & & & & & \\
\hline \multicolumn{7}{|l|}{$\begin{array}{l}\text { Significant Environmental } \\
\text { Variables }\end{array}$} \\
\hline & Df & $\mathrm{F}$ & $P$ & & & \\
\hline Emergent Macrophytes & 1 & 1.62 & 0.02 & & & \\
\hline Altitude & 1 & 2.03 & 0.015 & & & \\
\hline Pond Area & 1 & 2.25 & 0.01 & & & \\
\hline In Urban & 1 & 9.05 & 0.005 & & & \\
\hline
\end{tabular}

\begin{tabular}{lcccc}
\hline B: Eigenvalues for constrained axes in species-level RDA & & \\
\hline & RDA 1 & RDA 2 & RDA 3 & RDA 4 \\
\hline Eigenvalues & 0.250 & 0.128 & 0.076 & 0.064 \\
Proportion Explained (\%) & 1.02 & 0.55 & 0.32 & 0.28 \\
Cumulative Proportion Explained & 1.02 & 1.52 & 1.84 & 2.1 \\
$(\%)$ & & & & \\
\hline Adjusted $R^{2}$ & 0.01 & & & \\
\hline Significant Environmental & & & & \\
Variables & & $\mathrm{F}$ & $\mathrm{P}$ & \\
\hline & $\mathrm{Df}$ & 1.37 & 0.04 & \\
\hline Percentage pond shaded & 1 & 1.64 & 0.02 & \\
Area & 1 & 2.17 & 0.01 & \\
Altitude & 1 & 3.23 & 0.005 & \\
In Urban & 1 & & \\
\hline
\end{tabular}




\section{Part 2: Analysis excluding degraded ponds}

As discussed in the text, this analysis follows precisely the same methods as in the main part of the study but with the exclusion of sites which were explicitly recorded as being "degraded".
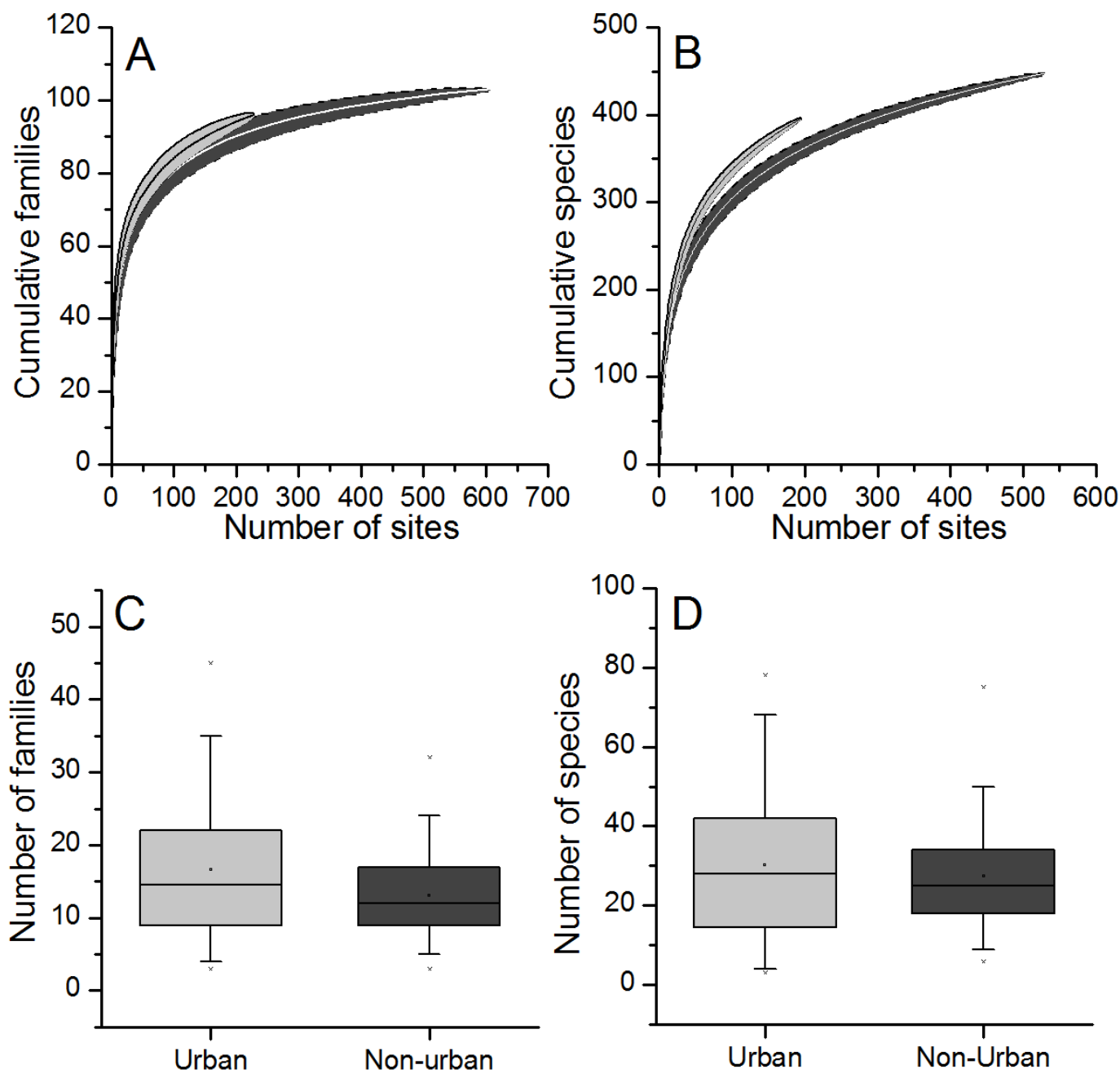

Figure S3 - Species accumulation curves of family richness (a) and species richness (b): grey area with black line $=$ urban ponds, black area with white line = non-degraded, non-urban ponds, and median macroinvertebrate family richness (c) and species richness (d) for urban and non-degraded, non-urban ponds. 
Table S5 - Homogeneity of multivariate dispersions for non-degraded, non-urban ponds at a family and species taxonomic scale.

\begin{tabular}{cccc}
\hline Taxonomic scale & Median & F & p-value \\
\hline Family & 0.398 & 28.323 & $<0.001$ \\
Species & 0.5504 & 17.439 & $<0.001$ \\
\hline
\end{tabular}

Table S6 - PERMANOVA results for urban and non-degraded, non-urban pond macroinvertebrate communities at a family and species level.

\begin{tabular}{ccc}
\hline PERMANOVA & $\mathbf{R}^{\mathbf{2}}$ & p-value \\
\hline Species & 0.030 & 0.001 \\
Family & 0.039 & 0.001 \\
\hline
\end{tabular}



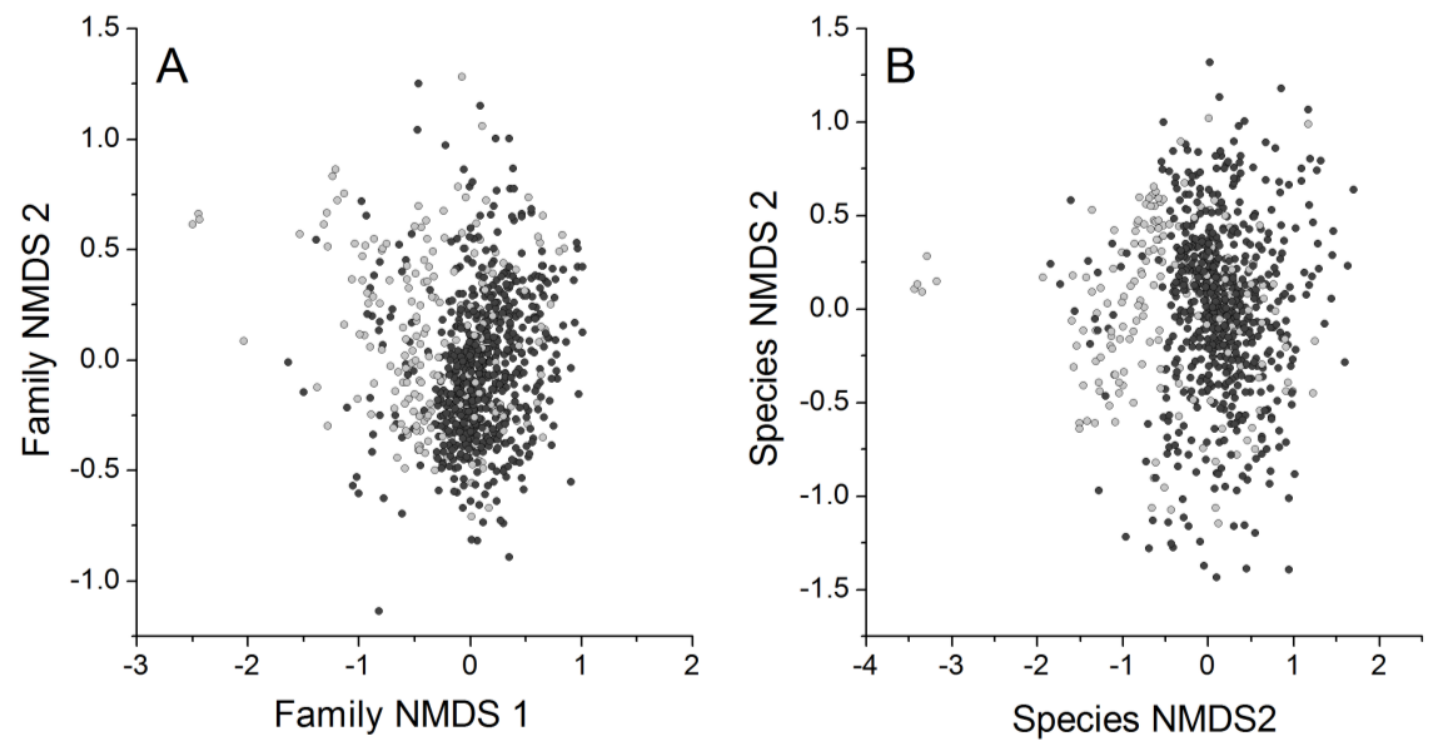

Figure S4 - Non-Metric Multidimensional scaling plots of variation in aquatic macroinvertebrate families (A) and aquatic macroinvertebrate species (B) from urban and non-degraded, non-urban ponds (dark grey symbols $=$ non-degraded, non-urban ponds and light grey symbols $=$ urban ponds). 

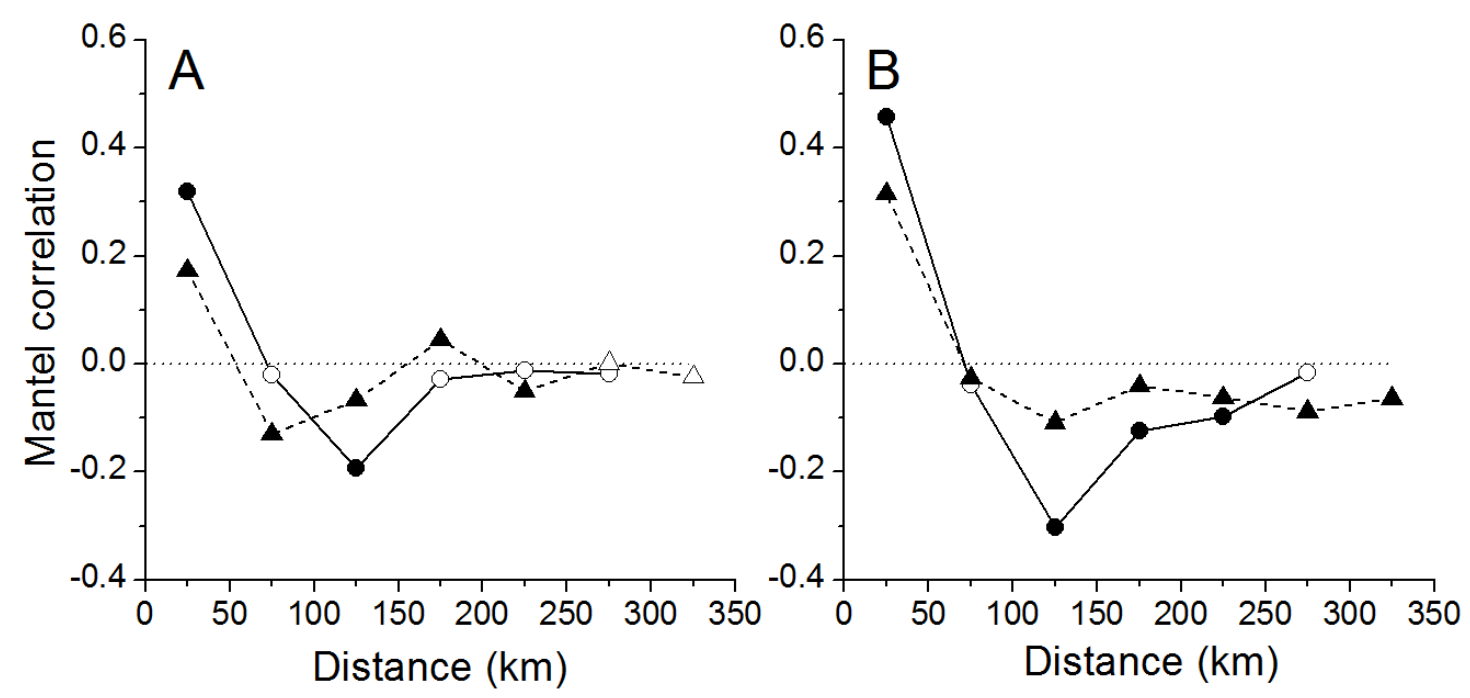

Figure S5 - Mantel correlogram for presence-absence macroinvertebrate family (A) and species $(B)$ data along $50 \mathrm{~km}$ distance intervals excluding known degraded sites. Triangles $=$ non degraded, non-urban macroinvertebrate communities, circles = urban macroinvertebrate communities. Filled symbols indicate statistically significant mantel correlations. 
Table S7 - Table of summary statistics for Redundancy Analysis of macroinvertebrate family $(A)$ and species (B) assemblage data for urban pond assemblages and non-degraded, nonurban pond assemblages (RDA axes were significant for the family $(F=3.085 p<0.001)$ and species $(F=1.70 p<0.001)$ models $)$.

\begin{tabular}{lcccc}
\hline (A) Eigenvalues for constrained axes (Family) & \multicolumn{4}{c}{} \\
\hline & RDA 1 & RDA 2 & RDA 3 & RDA 4 \\
\hline Eigenvalues & 0.21633 & 0.06478 & 0.02835 & 0.01456 \\
Proportion Explained (\%) & 0.02647 & 0.00792 & 0.00347 & 0.00178 \\
Cumulative Proportion Explained (\%) & 2.6 & 3.4 & 3.8 & 4.0 \\
\hline Adjusted $R^{2}$ & 0.03 & & & \\
\hline Significant Environmental Variables & & & & \\
\hline & Df & $\mathrm{F}$ & $\mathrm{P}$ & \\
\hline $\mathrm{pH}$ & 1 & 2.58 & 0.005 & \\
Area & 1 & 2.1 & 0.01 & \\
Altitude & 1 & 1.68 & 0.025 & \\
In Urban & 1 & 8.48 & 0.005 & \\
\hline
\end{tabular}

\begin{tabular}{lcccc}
\hline (B) Eigenvalues for constrained axes (Species) & & & \\
\hline & RDA 1 & RDA 2 & RDA 3 & RDA 4 \\
\hline Eigenvalues & 0.21553 & 0.17987 & 0.07284 & 0.06056 \\
Proportion Explained (\%) & 0.00958 & 0.00800 & 0.00324 & 0.00269 \\
Cumulative Proportion Explained (\%) & 0.96 & 1.76 & 2.08 & 2.35 \\
\hline Adjusted $R^{2}$ & 0.01 & & & \\
\hline Significant Environmental Variables & & & & \\
\hline & Df & $\mathrm{F}$ & $\mathrm{P}$ & \\
\hline Emergent Plants & 1 & 1.90 & 0.005 & \\
Altitude & 1 & 2.25 & 0.005 & \\
In Urban & 1 & 3.48 & 0.005 & \\
\hline
\end{tabular}



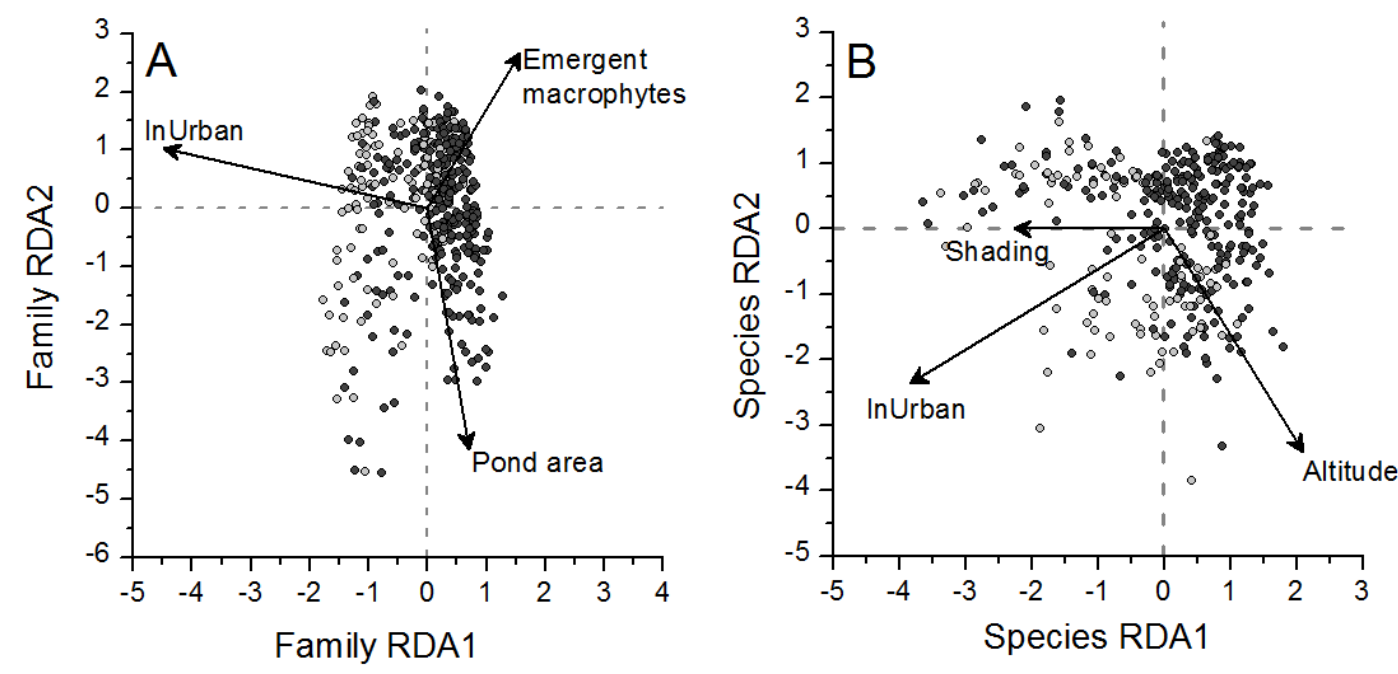

Figure S6 - RDA site plots of family (A) and species (B) macroinvertebrate communities recorded from the urban and non-degraded, non-urban pond types studied across the UK. Note - only significant environmental parameters are presented. Dark grey symbols $=$ nonurban ponds and light grey symbols $=$ urban ponds. 
Part 3: Species and family prevalence in urban and non-urban ponds

Table S8: Occurrence of aquatic macroinvertebrate families in urban ( $n=304)$ and non-urban $(n=607)$ ponds

\begin{tabular}{|c|c|c|c|c|}
\hline Family & $\begin{array}{l}\text { Non-urban } \\
\text { occurrence }\end{array}$ & $\begin{array}{l}\text { Urban } \\
\text { occurrence }\end{array}$ & $\begin{array}{l}\text { Non-urban } \\
\text { prevalence }\end{array}$ & $\begin{array}{l}\text { Urban } \\
\text { prevalence }\end{array}$ \\
\hline Acroloxidae & 50 & 33 & 0.082 & 0.109 \\
\hline Aeshnidae & 160 & 91 & 0.264 & 0.299 \\
\hline Ancylidae & 3 & 1 & 0.005 & 0.003 \\
\hline Anthribidae & 0 & 1 & 0.000 & 0.003 \\
\hline Aphelocheiridae & 8 & 5 & 0.013 & 0.016 \\
\hline Araneae & 22 & 3 & 0.036 & 0.010 \\
\hline Argulidae & 0 & 2 & 0.000 & 0.007 \\
\hline Asellidae & 376 & 199 & 0.619 & 0.655 \\
\hline Astacidae & 8 & 2 & 0.013 & 0.007 \\
\hline Baetidae & 333 & 154 & 0.549 & 0.507 \\
\hline Beraeidae & 2 & 3 & 0.003 & 0.010 \\
\hline Bibionidae & 1 & 0 & 0.002 & 0.000 \\
\hline Bithyniidae & 35 & 30 & 0.058 & 0.099 \\
\hline Brachycentridae & 2 & 0 & 0.003 & 0.000 \\
\hline Caenidae & 71 & 37 & 0.117 & 0.122 \\
\hline Calopterygidae & 2 & 1 & 0.003 & 0.003 \\
\hline Carabidae & 1 & 2 & 0.002 & 0.007 \\
\hline Ceratopogonidae & 1 & 36 & 0.002 & 0.118 \\
\hline Chaoboridae & 0 & 4 & 0.000 & 0.013 \\
\hline Chironomidae & 39 & 112 & 0.064 & 0.368 \\
\hline Chloroperlidae & 1 & 1 & 0.002 & 0.003 \\
\hline Chrysomelidae & 137 & 41 & 0.226 & 0.135 \\
\hline Cladocera & 1 & 2 & 0.002 & 0.007 \\
\hline Coccinellidae & 101 & 38 & 0.166 & 0.125 \\
\hline Coenagrionidae & 319 & 148 & 0.526 & 0.487 \\
\hline Copepoda & 2 & 3 & 0.003 & 0.010 \\
\hline Cordulegasteridae & 0 & 1 & 0.000 & 0.003 \\
\hline Corixidae & 497 & 224 & 0.819 & 0.737 \\
\hline Crambidae & 83 & 39 & 0.137 & 0.128 \\
\hline Crangonyctidae & 176 & 149 & 0.290 & 0.490 \\
\hline Culicidae & 1 & 34 & 0.002 & 0.112 \\
\hline Curculionidae & 19 & 3 & 0.031 & 0.010 \\
\hline Dendrocoelidae & 6 & 18 & 0.010 & 0.059 \\
\hline Dixidae & 2 & 35 & 0.003 & 0.115 \\
\hline Dryopidae & 31 & 6 & 0.051 & 0.020 \\
\hline Dugesidae & 49 & 37 & 0.081 & 0.122 \\
\hline Dytiscidae & 559 & 253 & 0.921 & 0.832 \\
\hline Ecnomidae & 6 & 0 & 0.010 & 0.000 \\
\hline Elmidae & 18 & 9 & 0.030 & 0.030 \\
\hline Ephemeridae & 4 & 1 & 0.007 & 0.003 \\
\hline Erpobdellidae & 174 & 98 & 0.287 & 0.322 \\
\hline Euconulidae & 5 & 1 & 0.008 & 0.003 \\
\hline Ferrissidae & 5 & 2 & 0.008 & 0.007 \\
\hline Gammaridae & 81 & 62 & 0.133 & 0.204 \\
\hline Gastrodontidae & 1 & 0 & 0.002 & 0.000 \\
\hline Gerridae & 268 & 128 & 0.442 & 0.421 \\
\hline Glossiphoniidae & 230 & 129 & 0.379 & 0.424 \\
\hline Glossosomatiidae & 1 & 1 & 0.002 & 0.003 \\
\hline Gyrinidae & 134 & 40 & 0.221 & 0.132 \\
\hline
\end{tabular}




\begin{tabular}{|c|c|c|c|c|}
\hline Haliplidae & 258 & 125 & 0.425 & 0.411 \\
\hline Hebridae & 10 & 0 & 0.016 & 0.000 \\
\hline Helodidae & 0 & 2 & 0.000 & 0.007 \\
\hline Heptageniidae & 12 & 1 & 0.020 & 0.003 \\
\hline Heteroceridae & 5 & 0 & 0.008 & 0.000 \\
\hline Hirudidae & 25 & 9 & 0.041 & 0.030 \\
\hline Hydrachnidae & 2 & 8 & 0.003 & 0.026 \\
\hline Hydraenidae & 148 & 38 & 0.244 & 0.125 \\
\hline Hydrobiidae & 57 & 63 & 0.094 & 0.207 \\
\hline Hydrometridae & 70 & 54 & 0.115 & 0.178 \\
\hline Hydrophilidae & 537 & 206 & 0.885 & 0.678 \\
\hline Hydropsychidae & 1 & 3 & 0.002 & 0.010 \\
\hline Hydroptilidae & 8 & 15 & 0.013 & 0.049 \\
\hline Hygrobiidae & 53 & 18 & 0.087 & 0.059 \\
\hline Lepidostomatidae & 3 & 2 & 0.005 & 0.007 \\
\hline Leptoceridae & 93 & 56 & 0.153 & 0.184 \\
\hline Leptophlebiidae & 17 & 13 & 0.028 & 0.043 \\
\hline Lestidae & 47 & 7 & 0.077 & 0.023 \\
\hline Leuctridae & 6 & 3 & 0.010 & 0.010 \\
\hline Libellulidae & 142 & 60 & 0.234 & 0.197 \\
\hline Limacidae & 14 & 10 & 0.023 & 0.033 \\
\hline Limnephilidae & 320 & 157 & 0.527 & 0.516 \\
\hline Limnichidae & 2 & 0 & 0.003 & 0.000 \\
\hline Lymnaeidae & 342 & 185 & 0.563 & 0.609 \\
\hline Mesoveliidae & 0 & 1 & 0.000 & 0.003 \\
\hline Microveliidae & 36 & 12 & 0.059 & 0.039 \\
\hline Nabidae & 75 & 58 & 0.124 & 0.191 \\
\hline Naucoridae & 94 & 39 & 0.155 & 0.128 \\
\hline Nemouridae & 57 & 20 & 0.094 & 0.066 \\
\hline Nepidae & 16 & 29 & 0.026 & 0.095 \\
\hline Neuroptera & 0 & 1 & 0.000 & 0.003 \\
\hline Niphargidae & 2 & 0 & 0.003 & 0.000 \\
\hline Noteridae & 61 & 51 & 0.100 & 0.168 \\
\hline Notonectidae & 350 & 150 & 0.577 & 0.493 \\
\hline Odontoceridae & 4 & 1 & 0.007 & 0.003 \\
\hline Oligochaeta & 34 & 99 & 0.056 & 0.326 \\
\hline Ostracoda & 2 & 3 & 0.003 & 0.010 \\
\hline Paguroidea & 3 & 2 & 0.005 & 0.007 \\
\hline Phryganeidae & 57 & 40 & 0.094 & 0.132 \\
\hline Physidae & 56 & 67 & 0.092 & 0.220 \\
\hline Piscicolidae & 16 & 11 & 0.026 & 0.036 \\
\hline Pisidiidae & 142 & 65 & 0.234 & 0.214 \\
\hline Planariidae & 185 & 81 & 0.305 & 0.266 \\
\hline Planorbidae & 339 & 183 & 0.558 & 0.602 \\
\hline Pleidae & 37 & 7 & 0.061 & 0.023 \\
\hline Polycentropodidae & 46 & 44 & 0.076 & 0.145 \\
\hline Potamanthidae & 6 & 2 & 0.010 & 0.007 \\
\hline Psychodidae & 0 & 30 & 0.000 & 0.099 \\
\hline Psychomyiidae & 7 & 5 & 0.012 & 0.016 \\
\hline Ptychopteridae & 0 & 5 & 0.000 & 0.016 \\
\hline Pyralidae & 6 & 5 & 0.010 & 0.016 \\
\hline Scirtidae & 74 & 37 & 0.122 & 0.122 \\
\hline Sericostomatidae & 4 & 1 & 0.007 & 0.003 \\
\hline Sialidae & 153 & 91 & 0.252 & 0.299 \\
\hline
\end{tabular}


Simuliidae

Siphlonuridae

Sphaeriidae

Stratiomyidae

Succineidae

Taeniopterygidae

Tipulidae

Tortricoidea

Unionidae

Valvatidae

Veliidae

Viviparidae

\begin{tabular}{rrrr}
0 & 5 & 0.000 & 0.016 \\
6 & 3 & 0.010 & 0.010 \\
44 & 69 & 0.072 & 0.227 \\
0 & 15 & 0.000 & 0.049 \\
30 & 7 & 0.049 & 0.023 \\
8 & 0 & 0.013 & 0.000 \\
14 & 55 & 0.023 & 0.181 \\
0 & 1 & 0.000 & 0.003 \\
12 & 0 & 0.020 & 0.000 \\
19 & 10 & 0.031 & 0.033 \\
32 & 19 & 0.053 & 0.063 \\
4 & 1 & 0.007 & 0.003 \\
\hline
\end{tabular}


Table S9: Occurrence of aquatic macroinvertebrate species in urban $(n=207)$ and non-urban $(n=577)$ ponds

\begin{tabular}{|c|c|c|c|c|}
\hline Species & $\begin{array}{l}\text { Urban } \\
\text { occurrence }\end{array}$ & $\begin{array}{l}\text { Non-urban } \\
\text { occurrence }\end{array}$ & $\begin{array}{l}\text { Urban } \\
\text { prevalence }\end{array}$ & $\begin{array}{l}\text { Non-urban } \\
\text { prevalence }\end{array}$ \\
\hline Acilius canaliculatus & 0 & 1 & 0.000 & 0.002 \\
\hline Acilius sulcatus & 19 & 81 & 0.092 & 0.140 \\
\hline Acroloxus lacustris & 25 & 54 & 0.121 & 0.094 \\
\hline Aeshna cyanea & 37 & 86 & 0.179 & 0.149 \\
\hline Aeshna grandis & 26 & 47 & 0.126 & 0.081 \\
\hline Aeshna juncea & 1 & 20 & 0.005 & 0.035 \\
\hline Aeshna mixta & 6 & 0 & 0.029 & 0.000 \\
\hline Agabus affinis & 2 & 11 & 0.010 & 0.019 \\
\hline Agabus arcticus & 1 & 1 & 0.005 & 0.002 \\
\hline Agabus bipustulatus & 74 & 303 & 0.357 & 0.525 \\
\hline Agabus chalconatus & 2 & 18 & 0.010 & 0.031 \\
\hline Agabus congener & 1 & 2 & 0.005 & 0.003 \\
\hline Agabus conspersus & 0 & 1 & 0.000 & 0.002 \\
\hline Agabus didymus & 0 & 3 & 0.000 & 0.005 \\
\hline Agabus guttatus & 0 & 2 & 0.000 & 0.003 \\
\hline Agabus labiatus & 0 & 5 & 0.000 & 0.009 \\
\hline Agabus melanarius & 0 & 10 & 0.000 & 0.017 \\
\hline Agabus melanocornis & 5 & 10 & 0.024 & 0.017 \\
\hline Agabus montanus & 1 & 8 & 0.005 & 0.014 \\
\hline Agabus nebulosus & 21 & 156 & 0.101 & 0.270 \\
\hline Agabus paludosus & 1 & 5 & 0.005 & 0.009 \\
\hline Agabus sturmii & 40 & 163 & 0.193 & 0.282 \\
\hline Agabus uliginosus & 7 & 13 & 0.034 & 0.023 \\
\hline Agraylea multipunctata & 12 & 5 & 0.058 & 0.009 \\
\hline Agraylea sexmaculata & 5 & 1 & 0.024 & 0.002 \\
\hline Agrypnia obsoleta & 5 & 5 & 0.024 & 0.009 \\
\hline Agrypnia pagetana & 4 & 2 & 0.019 & 0.003 \\
\hline Agrypnia varia & 3 & 11 & 0.014 & 0.019 \\
\hline Amphinemoura sulcicollis & 0 & 1 & 0.000 & 0.002 \\
\hline Anabolia nervosa & 6 & 17 & 0.029 & 0.029 \\
\hline Anacaena bipustulata & 3 & 19 & 0.014 & 0.033 \\
\hline Anacaena globulus & 39 & 135 & 0.188 & 0.234 \\
\hline Anacaena limbata & 68 & 259 & 0.329 & 0.449 \\
\hline Anacaena lutescens & 28 & 119 & 0.135 & 0.206 \\
\hline Anax imperator & 9 & 9 & 0.043 & 0.016 \\
\hline Ancylus fluviatilis & 1 & 3 & 0.005 & 0.005 \\
\hline Anisosticta 19 punctata & 11 & 72 & 0.053 & 0.125 \\
\hline Anisus leucostoma & 27 & 41 & 0.130 & 0.071 \\
\hline Anisus vortex & 27 & 107 & 0.130 & 0.185 \\
\hline Anodonta anatina & 0 & 1 & 0.000 & 0.002 \\
\hline Anodonta cygnea & 1 & 10 & 0.005 & 0.017 \\
\hline Apatamia muliebris & 1 & 0 & 0.005 & 0.000 \\
\hline Aphelocheirus aestivalis & 0 & 1 & 0.000 & 0.002 \\
\hline Aphthona nonstriata & 0 & 8 & 0.000 & 0.014 \\
\hline Aplexa hypnorum & 5 & 9 & 0.024 & 0.016 \\
\hline Aquarius paludum & 0 & 1 & 0.000 & 0.002 \\
\hline Arctocorisa germari & 1 & 4 & 0.005 & 0.007 \\
\hline Argyroneta aquatica & 2 & 41 & 0.010 & 0.071 \\
\hline Armiger crista & 42 & 110 & 0.203 & 0.191 \\
\hline Asellus aquaticus & 130 & 294 & 0.628 & 0.510 \\
\hline Asellus meridianus & 16 & 111 & 0.077 & 0.192 \\
\hline
\end{tabular}


Athripsodes aterrimus

Athripsodes bilineatus

Athripsodes cinereus

Austropotamobius pallipes

Baetis rhodani

Baetis vernus

Bathyomphalus contortus

Batracobdella paludosa

Beraea pullata

Beraeodes minutus

Berosus affinis

Berosus luridus

Berosus signaticollis

Bithynia leachi

Bithynia tentaculata

Brachycentrus subnubilus

Caenis horaria

Caenis luctuosa

Caenis macrura

Caenis rivulorum

Caenis robusta

Callicorixa praeusta

Callicorixa wollastoni

Cataclysta lemnata

Centroptilum pennulatum

Ceraclea fulva

Ceraclea nigronervosa

Cercyon convexiusculus

Cercyon granarius

Cercyon impressus

Cercyon marinus

Cercyon obsoletus

Cercyon sternalis

Cercyon tristis

Cercyon ustulatus

Ceriagrion tenellum

Chaetarthria seminulum

Chaetocnema concinna

Chalcoides aurea

Cheumatopsyche lepida

Chloroperla torrentium

Chrysolina polita

Cloeon dipterum

Cloeon simile

Coccidula rufa

Coelambus confluens

Coelambus impressopunctatus

Coelambus paralellogrammus

Coelostoma orbiculare

Coenagrion puella pulchellum

Colymbetes fuscus

Copelatus haemorrhoidalis

Corixa affinis

Corixa dentipes

$\begin{array}{ll}0.068 & 0.081 \\ 0.000 & 0.002 \\ 0.005 & 0.007 \\ 0.000 & 0.002 \\ 0.000 & 0.002 \\ 0.000 & 0.002 \\ 0.029 & 0.092 \\ 0.005 & 0.000 \\ 0.010 & 0.003 \\ 0.000 & 0.002 \\ 0.000 & 0.002 \\ 0.010 & 0.007 \\ 0.005 & 0.017\end{array}$

$0.010 \quad 0.019$

$0.106 \quad 0.061$

$0.000 \quad 0.002$

$0.116 \quad 0.045$

$0.043 \quad 0.031$

$0.000 \quad 0.002$

$0.024 \quad 0.005$

$0.024 \quad 0.033$

$0.140 \quad 0.080$

$0.019 \quad 0.005$

$0.097 \quad 0.068$

$0.005 \quad 0.003$

$0.005 \quad 0.000$

$0.000 \quad 0.002$

$0.087 \quad 0.128$

$0.005 \quad 0.003$

$0.000 \quad 0.012$

$0.010 \quad 0.009$

$0.000 \quad 0.002$

$0.000 \quad 0.007$

$0.000 \quad 0.016$

$0.019 \quad 0.042$

$0.000 \quad 0.007$

$0.000 \quad 0.003$

$0.005 \quad 0.003$

$0.000 \quad 0.003$

$0.000 \quad 0.002$

$0.000 \quad 0.002$

$0.000 \quad 0.010$

$0.531 \quad 0.490$

$0.043 \quad 0.066$

$0.053 \quad 0.083$

$0.014 \quad 0.024$

$0.082 \quad 0.132$

$0.000 \quad 0.002$

$0.058 \quad 0.101$

$\begin{array}{ll}0.275 & 0.359\end{array}$

$0.184 \quad 0.359$

$0.058 \quad 0.132$

$0.000 \quad 0.002$

$0.034 \quad 0.017$ 
Corixa panzeri

Corixa punctata

Corixidae nymph

0.242

0.412

Crangonyx pseudogracilis

Cymatia bonsdorffi

Cymatia coleoptrata

Cymbiodyta marginella

0.029

0.023

Cyphon coarctatus

Cyphon hilaria

0.000

0.005

Cyphon padi

Cyphon variabilis

Cyrnus flavidus

Cyrnus trimaculatus

Dendrocoelum lacteum

0.053

0.043

0.007

$0.000 \quad 0.002$

$0.034 \quad 0.010$

Deroceras laeve

Donacia marginata

Donacia simplex

Donacia versicolorea

Donacia vulgaris

Dryops ernesti

Dryops luridus

Dryops similaris

Dryops striatellus

Dugesia lugubris

Dugesia polychroa

Dugesia tigrina

Dytiscus circumcinctus

Dytiscus circumflexus

Dytiscus marginalis

Dytiscus semisulcatus

Ecdyonurus dispar

Ecnomus tenellus

Elmis aenea

Elophila nymphaeata

Enallagma cyathigerum

0.072

0.007

$0.068 \quad 0.014$

$0.010 \quad 0.024$

$0.000 \quad 0.003$

$0.024 \quad 0.049$

$0.005 \quad 0.002$

$0.005 \quad 0.023$

$0.000 \quad 0.002$

$0.014 \quad 0.035$

$0.000 \quad 0.012$

$0.000 \quad 0.005$

$0.034 \quad 0.042$

$0.097 \quad 0.019$

$0.082 \quad 0.028$

$0.000 \quad 0.003$

$0.000 \quad 0.023$

$0.111 \quad 0.092$

$0.010 \quad 0.017$

$0.000 \quad 0.002$

$0.000 \quad 0.003$

$0.005 \quad 0.007$

$0.063 \quad 0.107$

$0.111 \quad 0.158$

Enochrus affinis

$0.010 \quad 0.019$

Enochrus bicolor

Enochrus coarctatus

Enochrus fuscipennis

Enochrus halophilus

Enochrus isotae

Enochrus melanocephalus

0.000

0.002

$0.135 \quad 0.198$

$0.000 \quad 0.010$

$0.000 \quad 0.003$

$0.000 \quad 0.009$

$0.005 \quad 0.023$

Enochrus nigritus

0.000

0.002

$0.000 \quad 0.031$

Enochrus ochropterus

0.126

0.135

Ephemera danica

Ephemera vulgata

0.005

0.002

0.005

0.005

Ephemerella ignita

Erpobdella octoculata

0.000

0.002

Erpobdella testacea

0.217

0.236

Erythromma najas

0.169

0.090

Euconulus alderi

Ferrissia wautieri

Galerucella cf grisescens

0.058

0.057

0.005

0.009

0.010

0.009

0.000

0.003 
Galerucella sagittariae $\quad 0$

Gammarus lacustris

Gammarus pulex

Garrmarus zaddachi

Gastrophysa polygoni

Gerris argentatus

Gerris costai

Gerris gibbifer

Gerris lacustris

Gerris lateralis

Gerris odontogaster

Gerris thoracicus

Glossiphonia complanata

Glossiphonia heteroclita

Glyphotaelius pellucidus

Grammotaulius nigropunctatus

Graptodytes flavipes

Graptodytes granularis

Graptodytes pictus

Gyraulus albus

Gyraulus laevis

Gyrinus caspius

Gyrinus distinctus

Gyrinus marinus

Gyrinus substriatus

Gyrinus urinator

Haemopis sanguisuga

Halesus digitatus

Halesus radiatus

Haliplus confinis

Haliplus flavicollis

Haliplus fluviatilis

Haliplus fulvus

Haliplus heydeni

Haliplus immaculatus

Haliplus laminatus

Haliplus lineatocollis

Haliplus lineolatus

Haliplus obliquus

Haliplus ruficollis

Haliplus variegatus

Haliplus wehnckei

Hebrus pusillus

Hebrus ruficeps

Helobdella stagnalis

Helochares lividus

Helochares punctatus

Helophorus aequalis

Helophorus alternans

Helophorus avernicus

Helophorus brevipalpis

Helophorus dorsalis

Helophorus flavipes

Helophorus fulgidicollis $\begin{array}{ll}0.000 & 0.026\end{array}$

$0.019 \quad 0.000$

$0.280 \quad 0.120$

$0.000 \quad 0.002$

$0.000 \quad 0.005$

$0.000 \quad 0.009$

$0.000 \quad 0.002$

$0.024 \quad 0.005$

$0.343 \quad 0.331$

$0.000 \quad 0.007$

$0.058 \quad 0.094$

$0.043 \quad 0.081$

$0.179 \quad 0.159$

$0.072 \quad 0.121$

$0.106 \quad 0.076$

$0.014 \quad 0.010$

$0.000 \quad 0.005$

$0.005 \quad 0.016$

$0.005 \quad 0.029$

$0.319 \quad 0.260$

$0.019 \quad 0.003$

$0.000 \quad 0.005$

$0.005 \quad 0.000$

$0.010 \quad 0.057$

$0.097 \quad 0.146$

$0.005 \quad 0.002$

$0.053 \quad 0.080$

$0.000 \quad 0.002$

$0.010 \quad 0.010$

$0.077 \quad 0.033$

$0.010 \quad 0.052$

$0.005 \quad 0.019$

$0.029 \quad 0.045$

$0.005 \quad 0.012$

$0.043 \quad 0.069$

$0.010 \quad 0.007$

$0.077 \quad 0.123$

$0.010 \quad 0.005$

$0.029 \quad 0.035$

$0.304 \quad 0.308$

$0.000 \quad 0.002$

$0.014 \quad 0.049$

$0.000 \quad 0.003$

$0.000 \quad 0.010$

$0.333 \quad 0.205$

$0.116 \quad 0.132$

$0.039 \quad 0.092$

$0.058 \quad 0.090$

$0.000 \quad 0.002$

$0.000 \quad 0.002$

$0.329 \quad 0.589$

$0.000 \quad 0.002$

$0.024 \quad 0.049$

$0.000 \quad 0.002$ 
Helophorus grandis

Helophorus granularis

Helophorus griseus

Helophorus longitarsis

Helophorus minutus

Helophorus nanus

Helophorus obscurus

Helophorus strigifrons

Helophorus terrestrial

Helophorus tuberculatus

Hemiclepsis marginata

Heptagenea sulphurea

Hesperocorixa castanea

Hesperocorixa linnei

Hesperocorixa moesta

Hesperocorixa sahlbergi

Heterocerus fenestratus

Hippeutis complanatus

Hippuriphila modeeri

Holocentropus dubius

Holocentropus picicornis

Holocentropus stagnalis

Hydaticus seminiger

Hydraena britteni

Hydraena riparia

Hydraena testacea

Hydrobius fuscipes

Hydrochara caraboides

Hydrochus angustatus

Hydrochus brevis

Hydrochus carinatus

Hydrochus elongatus

Hydroglyphus geminus

Hydroglyphus pusillus

Hydrometra gracilenta

Hydrometra stagnorum

Hydroporus angustatus

Hydroporus discretus

Hydroporus erythrocephalus

Hydroporus glabriusculus

Hydroporus gyllenhalii

Hydroporus incognitus

Hydroporus longicornis

Hydroporus longulus

Hydroporus marginatus

Hydroporus melanarius

Hydroporus memnonius

Hydroporus neglectus

Hydroporus nigrita

Hydroporus obscurus

Hydroporus obsoletus

Hydroporus palustris

Hydroporus planus

Hydroporus pubescens

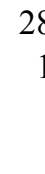

0.496

$0.019 \quad 0.019$

$0.010 \quad 0.010$

$0.000 \quad 0.002$

$0.174 \quad 0.211$

$0.014 \quad 0.019$

$0.063 \quad 0.127$

$0.010 \quad 0.007$

$0.014 \quad 0.000$

$0.000 \quad 0.002$

$0.043 \quad 0.017$

$0.000 \quad 0.002$

$0.029 \quad 0.062$

$0.116 \quad 0.139$

$0.053 \quad 0.017$

$0.348 \quad 0.433$

$0.000 \quad 0.005$

$0.213 \quad 0.184$

$0.000 \quad 0.014$

$0.024 \quad 0.028$

$0.039 \quad 0.029$

$0.010 \quad 0.012$

$0.024 \quad 0.033$

$0.000 \quad 0.002$

$0.029 \quad 0.047$

$0.019 \quad 0.024$

$0.401 \quad 0.513$

$0.010 \quad 0.005$

$0.005 \quad 0.029$

$0.000 \quad 0.002$

$0.000 \quad 0.005$

$0.005 \quad 0.007$

$0.010 \quad 0.026$

$0.010 \quad 0.000$

$0.000 \quad 0.002$

$0.203 \quad 0.123$

$0.184 \quad 0.255$

$0.005 \quad 0.016$

$0.058 \quad 0.125$

$0.000 \quad 0.003$

$0.048 \quad 0.101$

$0.029 \quad 0.064$

$0.000 \quad 0.002$

$0.000 \quad 0.002$

$0.000 \quad 0.002$

$0.000 \quad 0.002$

$0.072 \quad 0.125$

$0.039 \quad 0.024$

$0.048 \quad 0.106$

$0.014 \quad 0.029$

$0.010 \quad 0.000$

$0.275 \quad 0.435$

$0.222 \quad 0.468$

$0.058 \quad 0.133$ 
Hydroporus rufifrons

Hydroporus striola

Hydroporus tesselatus

Hydroporus tristis

Hydroporus umbrosus

Hydropsyche angustipennis

Hydrothassa marginella

Hydrovatus clypealis

Hygrobia hermanni

Hygrotus decoratus

Hygrotus inaequalis

Hygrotus versicolor

Hyphydrus ovatus

Hyrdochus ignicollis

Ilybius ater

Ilybius fenestratus

Ilybius fuliginosus

Ilybius guttiger

Ilybius quadriguttatus

Ilybius subaeneus

Ilyocoris cimicoides

Ischnura elegans

Ischnura pumilio

Laccobius atratus

Laccobius biguttatus

Laccobius bipunctatus

Laccobius colon

Laccobius minutus

Laccobius sinuatus

Laccobius striatulus

Laccobius ytenensis

Laccophilus hyalinus

Laccophilus minutus

Laccornis oblongus

Lasiocephala basalis

Lepidostoma hirtum

Leptocerus tineiformis

Leptophlebia marginata

Leptophlebia vespertina

Lestes sponsa

Leuctra fusca

Libellula depressa

Libellula quadrimaculata

Limnebius nitidus

Limnebius papposus

Limnebius truncatellus

Limnephilus affinis incisus

Limnephilus auricula

Limnephilus binotatus

Limnephilus bipunctatus

Limnephilus centralis

Limnephilus decipiens

Limnephilus extricatus

Limnephilus flavicornis

0.000

0.014

0.005

0.003 
Limnephilus griseus

Limnephilus hirsutus

Limnephilus ignavus

Limnephilus lunatus

Limnephilus marmoratus

0

Limnephilus nigriceps

Limnephilus politus

Limnephilus rhombicus

Limnephilus sparsus

Limnephilus stigma

Limnephilus vittatus

Limnius volckmari

Limnoxenus niger

Lymnaea auricularia

Lymnaea glabra

Lymnaea palustris

Lymnaea peregra

Lymnaea stagnalis

Lymnaea truncatula

Lype reducta

Megasternum obscurum

Mesovelia furcata

Microcara testacea

Micronecta poweri

Micronecta scholtzi

Micropterna lateralis

Microvelia buenoi

Microvelia pygmaea

Microvelia reticulata

Molanna angustata

Musculium lacustre

Mystacides azurea

Mystacides longicornis

Mystacides nigra

Myxas glutinosa

Nebrioporus depressus

Nebrioporus elegans

Nemoura cambrica

Nemoura cinerea

Nemurella picteti

Nepa cinerea

Niphargus aquilex

Noterus clavicornis

Noterus crassicornis

Notonecta glauca

Notonecta maculata

Notonecta marmorea

Notonecta obliqua

Nymphula stagnata

Ochthebius dilatatus

Ochthebius marinus

Ochthebius minimus

Ochthebius nanus

Ochthebius punctatus 
Ochthebius viridis $\quad 0$

Oecetis lacustris $\quad 2$

Oecetis ochracea 2

Oligotricha striata

Oreodytes sanmarkii

Orthetrum cancellatum

Orthetrum coerulescens

Oulimnius tuberculatus

Oxyloma pfeifferi

Paracorixa concinna

Paracymus scutellaris

Paraleptophlebia submarginata

Paraponyx stratiotata

Peltodytes caesus

Phaedon armoraciae

Phryganea bipunctata

Phryganea grandis

Physa acuta

Physa fontinalis

Physa heterostropha

Piscicola geometra

Pisidium casertanum

Pisidium hybernicum

Pisidium nitidum

Pisidium subtruncatum

Pisidium supinum

Planaria torva

Planorbarius corneus

Planorbis carinatus

Planorbis planorbis

Platambus maculatus

Plateumaris discolor

Plateumaris sericea

Plea leachi

Plectrocnemia conspersa

Polycelis felina

Polycelis nigra

Polycelis tenuis

Polycentropus flavomaculatus

Porhydrus lineatus

Potamanthus luteus

Potamonectes assimilis

Potamophylax latipennis

Potamopyrgus antipodarum

Prasocuris phellandrii

Prasocurus junci

Procloeon bifidum

Psylliodes affinis

Pyrrhosoma nymphula

Radix auricularia

Radix balthica

Ranatra linearis

Rhantus exsoletus

Rhantus frontalis

0.000

0.007

0.010

0.005

0.010

0.007

$0.000 \quad 0.003$

$0.000 \quad 0.002$

$0.010 \quad 0.003$

$0.000 \quad 0.003$

$0.010 \quad 0.012$

$0.019 \quad 0.042$

$0.019 \quad 0.000$

$0.000 \quad 0.014$

$0.000 \quad 0.002$

$0.005 \quad 0.005$

$0.005 \quad 0.005$

$0.043 \quad 0.080$

$0.087 \quad 0.017$

$0.000 \quad 0.002$

$0.116 \quad 0.035$

$0.111 \quad 0.038$

$0.005 \quad 0.000$

$0.039 \quad 0.016$

$0.005 \quad 0.003$

$0.014 \quad 0.002$

$0.005 \quad 0.003$

$0.014 \quad 0.005$

$0.005 \quad 0.000$

$0.005 \quad 0.000$

$0.213 \quad 0.088$

$0.106 \quad 0.097$

$0.087 \quad 0.050$

$0.005 \quad 0.003$

$0.000 \quad 0.002$

$0.000 \quad 0.003$

$0.043 \quad 0.083$

$0.005 \quad 0.005$

$0.000 \quad 0.005$

$0.053 \quad 0.049$

$0.159 \quad 0.276$

$0.005 \quad 0.002$

$0.000 \quad 0.059$

$0.000 \quad 0.002$

$0.000 \quad 0.002$

$0.005 \quad 0.002$

$0.213 \quad 0.095$

$0.005 \quad 0.033$

$0.000 \quad 0.010$

$0.000 \quad 0.002$

$0.000 \quad 0.007$

$0.179 \quad 0.153$

$0.010 \quad 0.000$

$0.019 \quad 0.000$

$\begin{array}{ll}0.034 & 0.009\end{array}$

$0.005 \quad 0.026$

$0.000 \quad 0.002$ 
Rhantus grapii

Rhantus suturalis

Rhantus suturellus

Scirtes hemisphaericus

Sericostoma personatum

Sialis fuliginosa

Sialis lutaria

Sigara concinna

Sigara distincta

Sigara dorsalis

Sigara falleni

Sigara fossarum

Sigara lateralis

Sigara limitata

Sigara nigrolineata

Sigara scotti

Sigara semistriata

Sigara stagnalis

Sigara venusta

Siphlonurus lacustris

Sisyra fuscata

Sphaerium corneum

Sphaerium rivicola

Stagnicola palustris

Stenophylax permistus

Stictonectes lepidus

Stictotarsus duodecimpustulatus

Succinea putris

Suphrodytes dorsalis

Sympetrum danae

Sympetrum flaviolum

Sympetrum fonscolombii

Sympetrum sanguineum

Sympetrum striolatum

Tanysphyrus lemnae

Theromyzon tessulatum

Tinodes waeneri

Triaenodes bicolor

Tricholeiochiton fagesii

Trichostegia minor

Trocheta bykowskii

Valvata cristata

Valvata macrostoma

Valvata piscinalis

Velia caprai

Viviparus contectus

Viviparus viviparus

Zonitoides nitidus

4

1

6

1

1

55

6

31

\begin{tabular}{rll}
3 & 0.000 & 0.005 \\
4 & 0.019 & 0.007 \\
4 & 0.005 & 0.007 \\
32 & 0.029 & 0.055 \\
4 & 0.005 & 0.007 \\
0 & 0.005 & 0.000 \\
141 & 0.266 & 0.244 \\
43 & 0.029 & 0.075 \\
117 & 0.150 & 0.203 \\
132 & 0.275 & 0.229 \\
63 & 0.135 & 0.109 \\
53 & 0.039 & 0.092 \\
53 & 0.116 & 0.092 \\
27 & 0.048 & 0.047 \\
56 & 0.063 & 0.097 \\
14 & 0.005 & 0.024 \\
17 & 0.005 & 0.029 \\
0 & 0.005 & 0.000 \\
2 & 0.000 & 0.003 \\
2 & 0.000 & 0.003 \\
0 & 0.005 & 0.000 \\
112 & 0.092 & 0.194 \\
0 & 0.005 & 0.000 \\
0 & 0.005 & 0.000 \\
1 & 0.000 & 0.002 \\
4 & 0.005 & 0.007 \\
8 & 0.000 & 0.014 \\
5 & 0.010 & 0.009 \\
59 & 0.053 & 0.102 \\
2 & 0.005 & 0.003 \\
1 & 0.000 & 0.002 \\
0 & 0.005 & 0.000 \\
34 & 0.039 & 0.059 \\
89 & 0.130 & 0.154 \\
17 & 0.010 & 0.029 \\
89 & 0.164 & 0.154 \\
2 & 0.024 & 0.003 \\
38 & 0.068 & 0.066 \\
1 & 0.000 & 0.002 \\
18 & 0.014 & 0.031 \\
1 & 0.000 & 0.002 \\
15 & 0.000 & 0.026 \\
2 & 0.000 & 0.003 \\
10 & 0.043 & 0.017 \\
8 & 0.019 & 0.014 \\
2 & 0.000 & 0.003 \\
2 & 0.005 & 0.003 \\
4 & 0.034 & 0.007 \\
\hline & & \\
\hline 3 & &
\end{tabular}


Table S10 - Aquatic macroinvertebrate families identified as statistically significant indicator species for urban or non-urban ponds.

\begin{tabular}{llrr}
\hline Habitat & Taxon & statistic & p-value \\
\hline Non-urban ponds & Nemouridae & 0.341 & 0.007 \\
& Heptageniidae & 0.196 & 0.021 \\
Urban ponds & & \\
& Chironomidae & 0.719 & 0.001 \\
& Oligochaeta & 0.690 & 0.001 \\
& Crangonyctidae & 0.632 & 0.001 \\
& Sphaeriidae & 0.511 & 0.001 \\
Ceratopogonidae & 0.477 & 0.001 \\
& Dixidae & 0.463 & 0.001 \\
& Hydrobiidae & 0.458 & 0.001 \\
& Culicidae & 0.449 & 0.001 \\
& Physidae & 0.447 & 0.001 \\
Psychodidae & 0.426 & 0.001 \\
& Hydrometridae & 0.412 & 0.001 \\
Nepidae & 0.377 & 0.001 \\
Dugesidae & 0.362 & 0.001 \\
Stratiomyidae & 0.302 & 0.001 \\
Hydroptilidae & 0.278 & 0.003 \\
Dendrocoelidae & 0.275 & 0.001 \\
Hydrachnidae & 0.213 & 0.001 \\
Chaoboridae & 0.161 & 0.01 \\
Ptychopteridae & 0.161 & 0.017 \\
Simuliidae & 0.161 & 0.014 \\
\hline
\end{tabular}


Table S11 - Aquatic macroinvertebrate species identified as statistically significant indicator species for urban or non-urban ponds.

\begin{tabular}{|c|c|c|c|}
\hline Habitat & Taxon & statistic & p-value \\
\hline \multirow[t]{24}{*}{ Non-urban ponds } & Hydroporus planus & 0.573 & 0.001 \\
\hline & Hydroporus pubescens & 0.390 & 0.001 \\
\hline & Helochares punctatus & 0.382 & 0.001 \\
\hline & Hydroporus erythrocephalus & 0.373 & 0.003 \\
\hline & Cymbiodyta marginella & 0.365 & 0.005 \\
\hline & Lymnaea truncatula & 0.362 & 0.001 \\
\hline & Copelatus haemorrhoidalis & 0.346 & 0.004 \\
\hline & Hydroporus gyllenhalii & 0.339 & 0.001 \\
\hline & Hydroporus tesselatus & 0.327 & 0.003 \\
\hline & Bathyomphalus contortus & 0.318 & 0.009 \\
\hline & Hesperocorixa castanea & 0.298 & 0.023 \\
\hline & Argyroneta aquatica & 0.298 & 0.004 \\
\hline & Hydroporus memnonius & 0.283 & 0.011 \\
\hline & Hydroporus umbrosus & 0.262 & 0.037 \\
\hline & Coelostoma orbiculare & 0.248 & 0.04 \\
\hline & Hydroporus tristis & 0.246 & 0.007 \\
\hline & Enochrus ochropterus & 0.246 & 0.004 \\
\hline & Hydroporus nigrita & 0.238 & 0.018 \\
\hline & Ilybius quadriguttatus & 0.234 & 0.05 \\
\hline & Haliplus flavicollis & 0.231 & 0.035 \\
\hline & Aeshna juncea & 0.223 & 0.015 \\
\hline & Hydroporus obscurus & 0.215 & 0.026 \\
\hline & Valvata cristata & 0.215 & 0.029 \\
\hline & Sigara scotti & 0.198 & 0.035 \\
\hline \multirow[t]{19}{*}{ Urban ponds } & Crangonyx pseudogracilis & 0.688 & 0.001 \\
\hline & Lymnaea stagnalis & 0.499 & 0.001 \\
\hline & Gammarus pulex & 0.480 & 0.001 \\
\hline & Planorbarius corneus & 0.468 & 0.001 \\
\hline & Potamopyrgus antipodarum & 0.442 & 0.001 \\
\hline & Hydrometra stagnorum & 0.409 & 0.003 \\
\hline & Erpobdella testacea & 0.406 & 0.001 \\
\hline & Physa fontinalis & 0.368 & 0.001 \\
\hline & Dugesia polychroa & 0.354 & 0.001 \\
\hline & Aeshna grandis & 0.347 & 0.002 \\
\hline & Dugesia tigrina & 0.338 & 0.001 \\
\hline & Phryganea bipunctata & 0.328 & 0.001 \\
\hline & Caenis horaria & 0.306 & 0.035 \\
\hline & Haliplus confinis & 0.295 & 0.003 \\
\hline & Dendrocoelum lacteum & 0.294 & 0.001 \\
\hline & Mystacides longicornis & 0.290 & 0.001 \\
\hline & Cataclysta lemnata & 0.285 & 0.001 \\
\hline & Physa acuta & 0.284 & 0.009 \\
\hline & Agraylea multipunctata & 0.281 & 0.001 \\
\hline
\end{tabular}




\begin{tabular}{llr} 
Micronecta poweri & 0.280 & 0.001 \\
Notonecta maculata & 0.265 & 0.001 \\
Cyrnus trimaculatus & 0.253 & 0.001 \\
Hesperocorixa moesta & 0.250 & 0.018 \\
Ilyocoris cimicoides & 0.250 & 0.002 \\
Libellula depressa & 0.247 & 0.004 \\
Hemiclepsis marginata & 0.237 & 0.011 \\
Anax imperator & 0.228 & 0.028 \\
Limnephilus decipiens & 0.220 & 0.004 \\
Aeshna mixta & 0.217 & 0.001 \\
Zonitoides nitidus & 0.217 & 0.002 \\
Piscicola geometra & 0.214 & 0.013 \\
Caenis rivulorum & 0.189 & 0.015 \\
Agraylea sexmaculata & 0.189 & 0.02 \\
Molanna angustata & 0.189 & 0.012 \\
Hygrotus versicolor & 0.182 & 0.039 \\
Paracorixa concinna & 0.177 & 0.008 \\
Gammarus lacustris & 0.177 & 0.011 \\
Radix balthica & 0.177 & 0.008 \\
Limnephilus binotatus & 0.168 & 0.041 \\
Agrypnia pagetana & 0.168 & 0.034 \\
\hline
\end{tabular}

\section{References}

Oskanen J, Kindt R, Legendre P, O'Hara B, Stevens MHM (2007) vegan: Community ecology package, R package version 1.8-8. http://cran.r-project.org/, http://r-forge.rproject.org/projects/vegan/.

$\mathrm{R}$ Core Team (2015) $R$ : A language and environment for statistical computing, R Foundation for Statistical Computing, Vienna, Austria, https:/www.R-project.org/. 